\title{
Driving factors behind subjective resilience on organic dairy sheep farms
}

\author{
Augustine Perrin $^{1}$ and Guillaume Martin ${ }^{1}$
}

\begin{abstract}
Organic sheep milk production under a protected designation of origin for Roquefort cheese in Aveyron, France, has developed over the past several years. This niche market provides farmers with a favorable economic context due to high and stable milk prices. However, a variety of risks threatens this favorable context. This raises questions about driving factors behind resilience of organic dairy sheep farms. Unlike previous studies, we assessed the subjective resilience of farms from the perspective of farmers. We assumed that the maintenance or improvement of farmers' satisfaction over time, despite a variety of disturbances, demonstrates the ability of farms to maintain their productive functions without undermining natural resources, while ensuring fair income and good working conditions. Based on analytical frameworks from research on livestock farming systems and social-ecological resilience, we aimed to understand the combined evolution of farm structure, farming practices, and farmers' satisfaction to identify the driving factors behind subjective resilience on organic dairy sheep farms. We observed a general trend for an increase in farm size. We also used sparse partial least squares analysis to relate changes in farmer satisfaction to changes in farm structure and farming practices. On the 36 organic dairy sheep farms studied, increasing ewe productivity was the main driving factor improving subjective farm resilience in a context of high milk prices. An increase in ewe productivity was often associated with high rates of feed concentrate distribution and a sharp decrease in grazing duration on a few farms. The change in farming practices resulting from this productivity paradigm highlighted a trend toward the conventionalization of organic sheep milk production. Underlying principles of this conventionalization were sometimes at odds with resilience factors of social-ecological systems reported in the literature. This calls for caution when using farmers' satisfaction as a proxy of farm resilience and suggests combining subjective assessment with more objective approaches.
\end{abstract}

Key Words: conventionalization; farmer satisfaction; farm management; organic dairy; sheep farm; subjective resilience

\section{INTRODUCTION}

Livestock farms evolve in a disturbed, uncertain, and challenging context. Climate change impacts the quality and yields of crops and pastures (Olesen and Bindi 2002) and livestock health (Gauly et al. 2013), which requires livestock farmers to develop adaptation and mitigation strategies (Rojas-Downing et al. 2017). Livestock products are sold on competitive globalized markets, and volatile prices result in a lack of economic viability for most farmers (Garrido 2016, Schulte et al. 2018). Besides environmental and economic instability, livestock farmers must also respond to new societal concerns about animal welfare and the environmental impacts of their practices (Caracciolo et al. 2016). This uncertain context challenges the ability of farms, as social-ecological systems, to cope with disturbances of variable intensity, which may result in consequences that remain over the long term (Dedieu and Ingrand 2010).

The concept of social-ecological resilience has gained interest in the field of agricultural science. Consequently, the resilience framework has been adapted to farms as complex and dynamic systems (Darnhofer 2014). A resilient farm is able to maintain its productive functions over the long term despite disturbances (e. g., sudden shocks, unpredictable "surprises," slow-onset changes). Integrating the buffer capacity (i.e., ability to absorb disturbances without modifying the state of the system), adaptability (i.e., ability to adapt to current or potential future disturbances), and transformability (i.e., ability to make drastic changes and redesign a farm completely) enables farms to be resilient (Darnhofer 2014).

As in other fields of application (e.g., ecology, engineering sciences, psychology), the concept of resilience applied to agricultural systems remains abstract and multidimensional, and thus difficult to render operational (Cumming et al. 2005). The few studies that have assessed resilience in agroecosystems often focused on the evolution of objective performance indicators such as crop yields ( $\mathrm{Li}$ et al. 2019) and economic profitability (Groot et al. 2016). However, these resilience indicators remained at the subsystem scale (e.g., field) and lacked a holistic view of farms as units that consist of multiple, interrelated subsystems (e.g., land, flock, farmer). These assessments also often ignored the social component of farms. Cabell and Oelofse (2012) developed an indicator framework that includes the social component by using indicators related to the ability to learn from experiences or to build human capital. This framework later served as a basis for the SHARP farm-resilience assessment tool (Diserens et al. 2018). However, this tool focuses on farm resilience to a single type of disturbance - climate change - whereas holistic approaches are required to assess farm resilience over the middle-to-long term and to a diversity of disturbances (e.g., economic crises, life risks) (Kaseva et al. 2019, Meuwissen et al. 2020).

Farmers lie at the heart of farms as social-ecological systems. Each farmer has his/her own perceptions of the world and thus his/her own subjectivity (i.e., cognitive ability to effectively selfevaluate their farm's resilience). Because previous assessments of household/farm resilience have ignored this subjectivity, Jones and Tanner (2017) recommended assessing subjective resilience in addition to applying objective methods. Doing so requires giving relevance to farmers' cognitive self-evaluation of their farms' resilience over time. Farmers can be questioned about subjective farm resilience in many ways, each with its own advantages and biases, from fully qualitative approaches based on semi-structured interviews to more quantitative and structured approaches based on multiple-choice questions (Jones and 
Fig. 1. Analytical framework used to relate the evolution of subjective resilience to farm structure and farmers' management practices over time. "Inter." means intermediate.

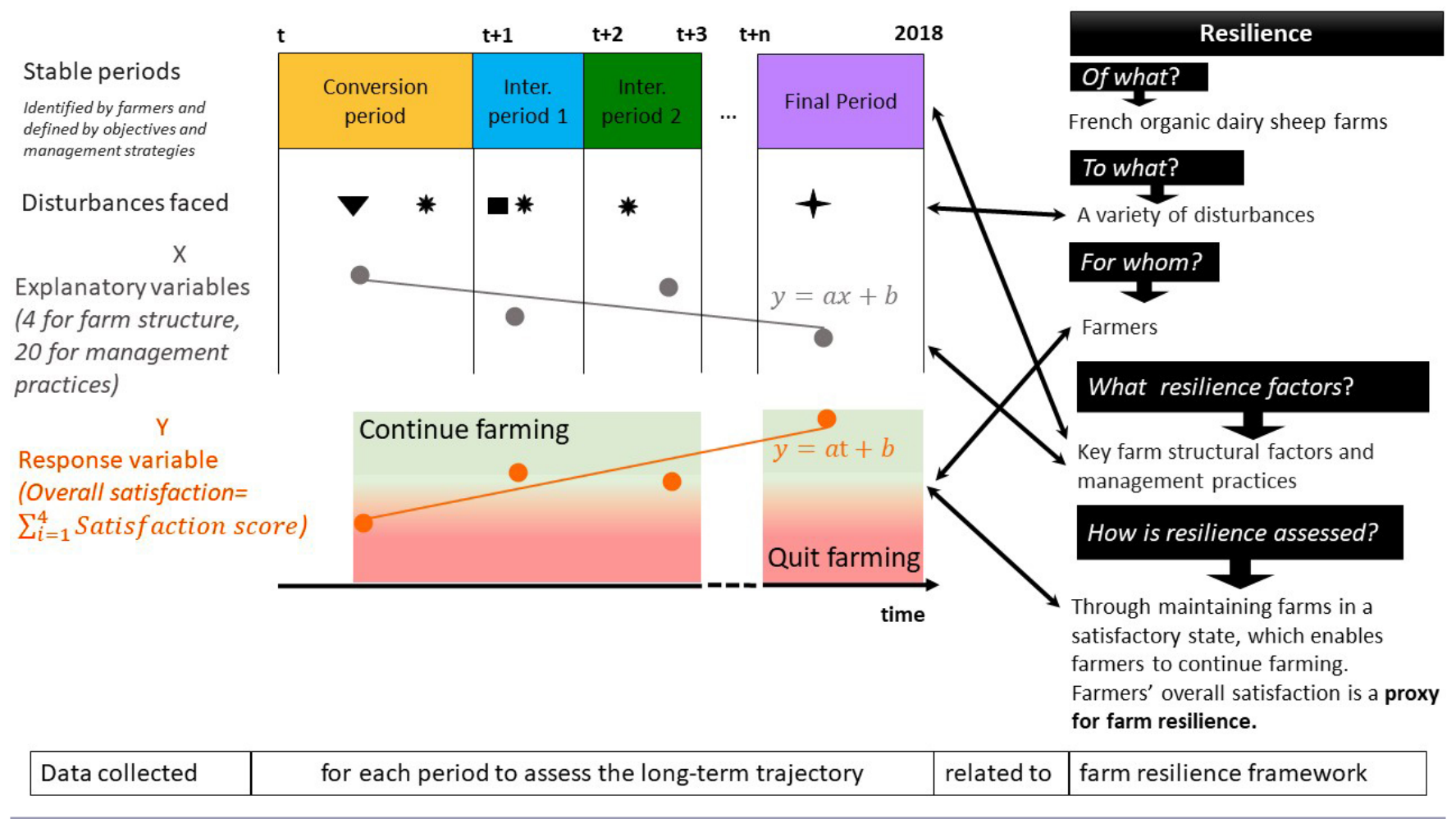

Tanner 2017). For both approaches, collecting information about subjective resilience remains challenging due to ambiguities surrounding the term.

We studied the subjective resilience of organic dairy sheep farms that produce milk in the area of Roquefort cheese production in Aveyron, France. This case study of livestock farms was chosen for two main reasons:

1. To date, few studies have addressed the performance of organic dairy sheep farms (Toro-Mujica et al. 2011, 2012), and no study has addressed the dynamics of the performance over the long term to assess farm resilience. However, organic dairy sheep farms in southwestern France have faced many disturbances over the past several years.

2. Organic farming is often highlighted as a way to improve farm resilience to a variety of disturbances (Milestad and Darnhofer 2003). For example, organic farms that produce under protected designation of origin (PDO) certification are more resilient to price fluctuations. However, farm resilience in the unique context of organic farming and a well-known PDO (for Roquefort cheese) needs to be studied.

In this study, we (i) monitored the evolution of farm structure and farming practices over long timeframes (5 years and more), (ii) described subjective resilience of organic dairy sheep farms to a variety of disturbances, and (iii) characterized relations among the evolution of farm structure, farmers' practices, and subjective farm resilience to identify driving factors behind resilience.

\section{MATERIALS AND METHODS}

Analytical Framework

We defined the resilience of organic dairy sheep farms as their ability to cope with all types of disturbances over the long term while successfully maintaining their productive functions (Walker et al. 2004). We built the dynamic component of the analytical framework using two bodies of literature: studies of livestock farming system trajectories and social-ecological resilience, especially farm resilience (Fig. 1). Both consider the evolution of farms over time as a process of responding to internal or external disturbances (Moulin et al. 2008, Darnhofer 2014). To understand this dynamic process further, it is recommended to identify stable periods (i.e., "consistent phases") (Davoudi et al. 2012). Each period is characterized by temporal consistency in farm structure and the farmer's management practices and objectives. In each period, the farmer relies mainly on the farm's buffering capacity and occasionally on minor adaptations (e.g., purchasing fodder) to cope with disturbances. The period lasts until the farmer's objectives and farm performances no longer match, or when the impacts of disturbances force the farmer to adapt or transform the farming system to obtain new temporal consistency. We thus considered farm trajectories as a sequence of farmer-defined periods that corresponded to relative stability in structure and management practices despite disturbances and changes. We did not study the transition between two periods in detail, but instead considered long-term trends of variables to identify key attributes of farm resilience (e.g., incorporating diversity (Dumont et al. 2020), increasing autonomy (Heiberg and Syse 2020)). 
We built the subjective resilience component of our analytical framework based on the literature on job satisfaction (Green 2010) and global life satisfaction (Cohn et al. 2009). Between 2005-2016, the number of livestock farms in the European Union decreased by $37.6 \%$ (European Commission 2019). Key factors for this decrease include inadequate income and the working conditions of livestock farming (Maucorps et al. 2019), which decrease job satisfaction and often overall life satisfaction. Lack of job satisfaction is associated with an increase in quitting (Green 2010), which holds true for the farming sector. Thus, monitoring farmers' satisfaction over the long term appears to be a simple way to determine subjective farm resilience to multiple disturbances. Armitage et al. (2012) demonstrated the potential of well-being, which is strongly related to job satisfaction (Green 2010) and overall life satisfaction (Cohn et al. 2009), to reflect subjective resilience holistically. Previous studies highlighted interactions between resilience and well-being (Greenhill et al. 2009, Armitage et al. 2012). Thus, we assumed that the evolution of farmers' satisfaction with the condition of their land, flock, and economic and social life over time can be used as a proxy of farm resilience to multiple disturbances over the middle-to-long term. Thus, farms with satisfactory land and flock conditions and that provide a fair income and good working conditions over the long term are better able to maintain their productive functions despite disturbances. In contrast, farmers' dissatisfaction compromises the long-term continuity of farming and progressively erodes the identity of farms as production units. We thus considered subjective farm resilience as a long-term trend that maintains or improves farmers' satisfaction. We then related these trends to variables that represented farm structure and farmers' management practice to identify driving factors behind subjective resilience.

\section{Case Study}

Aveyron is located on the southern border of the Massif Central, France. It is the main sheep milk production region in France, where Roquefort cheese is produced. Roquefort cheese was the first PDO product in France in 1925. Although the PDO is supposed to ensure high and stable milk prices for farmers, conventional Roquefort cheese production has encountered many difficulties, including a $15 \%$ decrease in production from $2007-$ 2017 (Spelle and Daudé 2019). At the same time, costs of conventional milk production have increased (Institut de l'élevage (IDELE) 2018). Faced with this unstable situation, conventional farmers have increasingly converted their farms to organic farming (Fig. 2b), in part due to a higher and increasing price for sheep milk (Fig. 2a). This trend has increased the percentage of organic dairy sheep farms in the region (Fig. 2c).

Along with this expansion, the organic dairy sheep sector faced a number of disturbances. Like many other livestock farms in France, organic dairy sheep farms in Aveyron experienced a sudden increase in input prices after the economic crisis of 20082009. The climate in Aveyron is Mediterranean, which limits land productivity, and climate change has resulted in frequent summer droughts, which decreased pasture yields and worsened the farms' already low self-sufficiency in fodder (Vial 2017). These farms also experienced the recent arrival of wolves in the area, along with unexpected international political disagreements (e.g., the Chinese embargo on Roquefort cheese in 2017 threatened production and the market (Boffet 2017)).
Fig. 2. (a) Mean organic and conventional sheep milk prices in the Roquefort protected designation of origin production area in France during milk-collection campaigns from 2014-2018 (BioReferences Project, 2016-2020). (b) Number of sheep milk farmers (total and organic) in the Aveyron department and Occitanie region from 2014 to 2018 (Agence Bio 2018,

FranceAgriMer 2020). (c) Share of organic sheep milk farmers in total sheep milk producers in Occitanie from 2014 to 2018 (Agence Bio 2018, FranceAgriMer 2020).
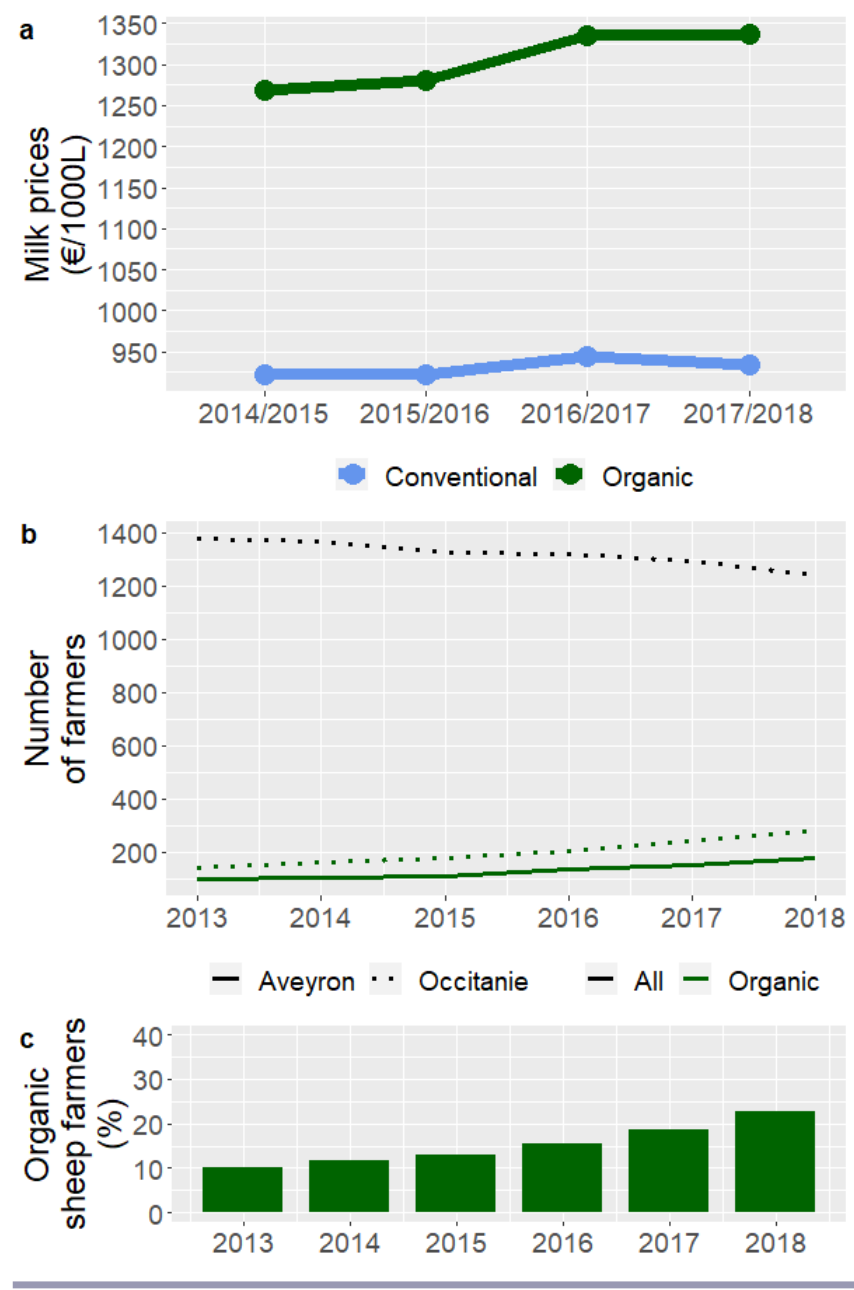

\section{Data Collection}

We interviewed 36 organic dairy sheep farmers in Aveyron (Fig. 3 ) in winter 2017-2018. Interviewers came from several organizations (i.e., a Chamber of Agriculture, two farmers' associations, an agricultural high school, and a research institute) involved in the "Résilait" project (Institut de l'agriculture et de l'alimentation biologiques (ITAB) 2017). The status of the interviewers varied (i.e., researchers, advisers, veterinarians, interns, and students). Interviewers helped design the survey guide, from defining the list of variables of interest to formulating the questions. All interviewers were trained in using the survey guide to ensure homogeneity in the survey process. 
Fig. 3. Number of organic dairy sheep farms per department in France in 2018. It peaked in the Aveyron department, where 36 organic dairy sheep farms were surveyed in winter 2017-2018. (Adapted from Agence Bio (2018).)

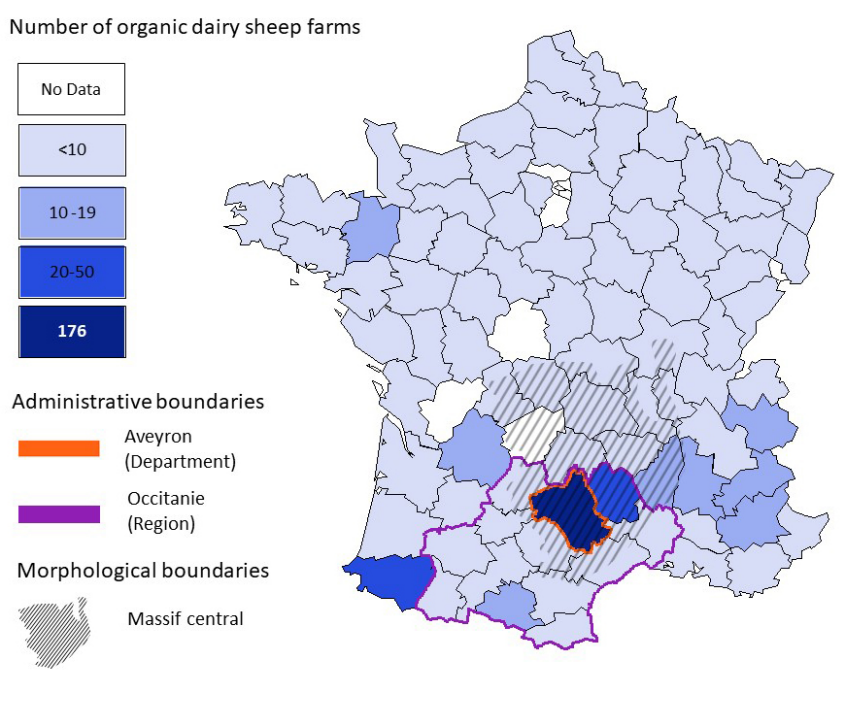

Each organization was responsible for finding farms within its own network and for contacting farmers. To consider only farms with a "routine" organic system, farms had to have converted to organic at least 5 years before the survey. The organizations had known the sampled farms for several years and had sometimes monitored their technical and/or financial characteristics. The organizations selected only farms that delivered milk to dairies (i. e., not those that processed their own milk) and that had proven their ability to maintain their productive functions despite the disturbances they had encountered since they began their conversion to organic. For example, these organizations knew the extent to which farms had been affected technically and economically by the 2017 summer drought and how they had coped with that event. Ultimately, the 36 -farm sample represented $38 \%$ of the 95 local organic dairy sheep farms that had been certified organic for at least 5 years (Agence Bio 2018). Until this study, data on organic dairy sheep farms had been limited to a 15-farm network in the Massif Central (De Boissieu et al. 2020). Compared with these, the farms surveyed in this study had fewer permanent workers and livestock units (LU) but more utilized agricultural area (UAA) (Table 1).

During face-to-face interviews, farmers first divided the history of their farms into several stable periods on a timeline. Starting from their conversion to organic farming, farmers thus identified different stable periods. Farmers then added values to the timeline for four farm structure variables and 20 agricultural practice variables (Table 2). The variables were defined by the group of researchers, advisers, teachers, and farmers (other than those who were surveyed) who contributed to the project. They are standard agricultural variables necessary to understand the overall functioning of livestock farms and were used in previous studies of the vulnerability and resilience of organic dairy farms in France (Bouttes et al. 2019, Perrin et al. 2020a).
Table 1. Mean, standard deviation, and range of characteristics of the farms surveyed in this study $(n=36)$ and farms in a previously studied network of organic dairy sheep farms in the Massif Central ( $n=15$ ) (De Boissieu et al. 2020).

\begin{tabular}{lll}
\hline \hline Characteristic & Surveyed farms & $\begin{array}{l}\text { Network } \\
\text { farms }\end{array}$ \\
\hline Permanent workers & $2.5 \pm 0.8 \epsilon[1 ; 6]$ & 2.9 \\
Utilized agricultural area (ha) & $184 \pm 124 \epsilon[53 ; 769]$ & 117.5 \\
Livestock units & $67 \pm 27 \in[19 ; 204]$ & 99.9 \\
Time since conversion (year) & $14 \pm 8 \in[6 ; 49]$ & No data \\
\hline
\end{tabular}

Farmers also added values to the timeline to indicate their level of satisfaction with each of four dimensions defined by the project group. For each stable period, farmers were asked how satisfied they were at that time and rated this level on a scale of 1-4 ("very unsatisfied", "unsatisfied", "satisfied," or "very satisfied", respectively) to clearly distinguish satisfactory from unsatisfactory situations and decrease the attractiveness of a "neutral" answer (Krosnick et al. 2001). Farmers were not provided with any indicators (e.g., yield, income) to support their assessment beyond the names of the dimensions:

- Land: satisfactory land conditions are necessary to produce sufficient quantity and quality of feed to cope with disturbances better.

- Animal: a satisfactory flock indicates that the farm can continue to produce milk despite disturbances.

- Economic: a good economic situation is crucial. Satisfaction with farm economics indicates sufficient room for farmers to manoeuvre in response to unforeseen events.

- Social: satisfaction with one's social situation is necessary to farm over the long term without becoming exhausted or disinterested.

For each stable period, the four dimensions were summed to calculate the response variable "overall satisfaction"(OverallSat), which was used as a proxy for farm resilience:

Overall Satisfaction= Land Satisfaction +Animal Satisfaction+ Economic Satisfaction+ Social Satisfaction

This summing created a dynamic and complex proxy for resilience that is consistent with long-term observations of social-ecological systems such as farms, in accordance with Carpenter et al. (2005). Each satisfaction dimension had the same weight when calculating overall satisfaction. Even though a farmer's relative preferences in the four dimensions may have changed over time, weighting the four dimensions for each stable period would have made data collection far more complex.

To assess subjective farm resilience to multiple disturbances, farmers described the disturbances they had experienced since their conversion to organic farming and specified the years when these disturbances had occurred. The interviewer classified disturbances into six types: climatic (e.g., droughts, hailstorms, wet years with poor harvests), economic (e.g. economic crises, increases in input prices), health related (e.g., disease outbreaks, abortions, parasitism), organizational (e.g., departure of an associate, personal health problem), technical (e.g., machine 
Table 2. Variables used to describe organic dairy sheep farms and assess their resilience. All variables for structure and practices are explanatory.

\begin{tabular}{|c|c|c|c|}
\hline $\begin{array}{l}\text { Category } \\
\text { Variable }\end{array}$ & Details & Abbreviation & Unit (calculation) \\
\hline \multicolumn{4}{|l|}{ Farm structure and size } \\
\hline Utilized agricultural area & $\begin{array}{l}\text { Total area: arable land, permanent grassland, permanent } \\
\text { crops, and kitchen gardens (Eurostat 2017a) }\end{array}$ & UAA & ha \\
\hline $\begin{array}{l}\text { Number of productive } \\
\text { ewes }\end{array}$ & $\begin{array}{l}\text { Number of dairy ewes daily milked on farm during the } \\
\text { milking period }\end{array}$ & Ewe & $\varnothing$ \\
\hline Number of lambs & Number of lambs born on farm each production season & Lamb & $\varnothing$ \\
\hline Livestock units & $\begin{array}{l}\text { Grazing equivalent of one dairy cow producing } 3,000 \mathrm{~kg} \text { of } \\
\text { milk per year, without being fed additional concentrates } \\
\text { (Eurostat } 2017 \mathrm{~b} \text { ) }\end{array}$ & LU & $\mathrm{LU}=0.15 \times$ number of ewes $+0.03 \times$ number of lambs \\
\hline \multicolumn{4}{|l|}{ Agricultural practices } \\
\hline Ewes per work unit & Number of dairy ewes milked per full-time worker & EweW & Number of ewes per work unit \\
\hline Hectares per work unit & Number of ha managed per full-time worker & $\mathrm{HaW}$ & Number of ha per work unit \\
\hline Area used to feed livestock & Percentage of the UAA used to produce fodder to feed sheep & AFL & $\%$ of UAA \\
\hline Permanent pasture area & Percentage of permanent pasture in the UAA & PerPast & $\%$ of UAA \\
\hline Temporary pasture area & Percentage of temporary pasture in the UAA & TemPast & $\%$ of UAA \\
\hline Maize area & Percentage of maize in the UAA & Maize & $\%$ of UAA \\
\hline Non-maize crop area & Percentage of non-maize crops in the UAA & Crops & $\%$ of UAA \\
\hline Other area & Percentage of other crops in the UAA & Others & $\%$ of UAA \\
\hline $\begin{array}{l}\text { Percentage of pastures in } \\
\text { UAA }\end{array}$ & $\begin{array}{l}\text { Percentage of permanent and temporary pastures in the } \\
\text { UAA }\end{array}$ & Pastures & $\%$ of UAA (PerPast + TemPast) \\
\hline Stocking rate & Number of LU per ha of AFL & StockRate & Livestock units per ha $(\mathrm{LU} /(\mathrm{AFL} \times \mathrm{UAA})$ \\
\hline Ewe productivity & Milk production per ewe per year & EweProd & L milk/ewe/year \\
\hline Lambing period & Date of the beginning of lambing & Lambing & Day of year \\
\hline Date of turnout to grazing & Date of the beginning of the grazing period & Turnout & Day of year \\
\hline Duration of grazing & Length of the grazing period & GrazDur & Number of months \\
\hline Duration of full grazing & $\begin{array}{l}\text { Length of the period during which ewes only graze (no other } \\
\text { feedstuff) }\end{array}$ & FullGrazDur & Number of months \\
\hline Duration of green feeding & $\begin{array}{l}\text { Length of the period during which dairy ewes are fed fresh } \\
\text { fodder }\end{array}$ & GFeedDur & Number of months \\
\hline Concentrate-use efficiency & $\begin{array}{l}\text { Amount of concentrates distributed to the flock each year, } \\
\text { normalized per L of milk }\end{array}$ & ConcDist & $\mathrm{g} / \mathrm{L}$ milk/year \\
\hline Self-sufficiency in fodder & $\begin{array}{l}\text { Proportion of total fodder consumption met by on-farm } \\
\text { fodder production, on a dry-matter basis }\end{array}$ & SSFod & SSFod $=1$ - (fodder purchases / total fodder consumption) \\
\hline $\begin{array}{l}\text { Self-sufficiency in } \\
\text { concentrates }\end{array}$ & $\begin{array}{l}\text { Proportion of total concentrate consumption met by on- } \\
\text { farm concentrate production, on a dry-matter basis }\end{array}$ & SSConc & $\begin{array}{c}\text { SSConc }=1-(\text { concentrate purchases } / \text { total concentrate } \\
\text { consumption })\end{array}$ \\
\hline \multicolumn{4}{|l|}{ Farmers' satisfaction } \\
\hline Land dimension & e.g., with the quality and yields of crops and pastures & LandSat & Score from $1-4$ \\
\hline Animal dimension & e.g., with animal health, prolificacy, and productivity & AnimSat & Score from $1-4$ \\
\hline Economic dimension & e.g., with income and financial flexibility & EconSat & Score from $1-4$ \\
\hline Social dimension & e.g., with free time and working conditions & SociSat & Score from $1-4$ \\
\hline \multicolumn{4}{|l|}{ Resilience proxy } \\
\hline Overall satisfaction & $\begin{array}{l}\text { Farmer's overall satisfaction, as the sum of the four } \\
\text { dimensions }\end{array}$ & OverallSat & $\begin{array}{c}\text { Score from 4-16 } \\
(\text { LandSat }+ \text { AnimSat }+ \text { EconSat }+ \text { SociSat })\end{array}$ \\
\hline
\end{tabular}

breakdown), and “other." Interviewers also provided a timeline that specified the main disturbances in Aveyron over the previous 10 years. It was used as a reference to identify whether farmers cited, and thus experienced, these reference disturbances (Fig. 4). Farmers were interviewed at their home or workplace for 2-3 hours, which was the most suitable format for collecting the data and reconstructing the farm history to accurately reflect farmers' statements and descriptions of stable periods.

\section{Statistical Analysis}

The disturbances experienced by social-ecological systems, the response to these disturbances, and the capacity for adaptive action are common elements when applying the concepts of vulnerability and resilience (Adger 2006) to farms. Martin et al. (2017) developed a method to assess the vulnerability of farms to climatic and economic variability. We adapted this method to the resilience framework. The method consists of performing one linear regression for each variable of each farm throughout the stable periods the farmer identified. We used the $\operatorname{lm}()$ function (fitting linear models) of the stats package of $\mathrm{R}$ software to perform the linear regressions (Ballesteros 2008). This first step generated both intercepts and slopes (called "I. $<$ Variable name $>$ " and "Ev. $<$ Variable name $>$ ", respectively; Table 2). The slopes showed how farm structure, farmers' practices, and farmers' overall satisfaction evolved over time. The intercepts estimated the state of the farm and the farmer during the period of conversion to organic farming. These mathematical parameters were then included in several iterations of partial least squares (PLS) analysis and sparse PLS (sPLS) analysis performed with the pls() and $\operatorname{spls}()$ functions of the mixOmics package of $\mathrm{R}$ software (Append. 1) (Tenenhaus 1998, Lê Cao et al. 2008). This method provided a holistic approach to relate the response variable - evolution of overall satisfaction-to explanatory variables that were divided into intercepts and slopes. The PLS results indicated the extent to which models were predictive $\left(\mathrm{Q}^{2}\right.$ values) and explanatory ( $\mathrm{R}^{2}$ values). We always performed the sPLS after PLS to obtain clearer and more robust results. The 
Fig. 4. Stable periods (CP: conversion period, IP1: intermediate period 1, IP2: intermediate period 2, SP: survey period) identified and disturbances experienced on farms. Although the earliest conversion to organic farming of farms in the sample was in 1984 (farm F26), the temporal scale starts in 1998 to distinguish the disturbances better.

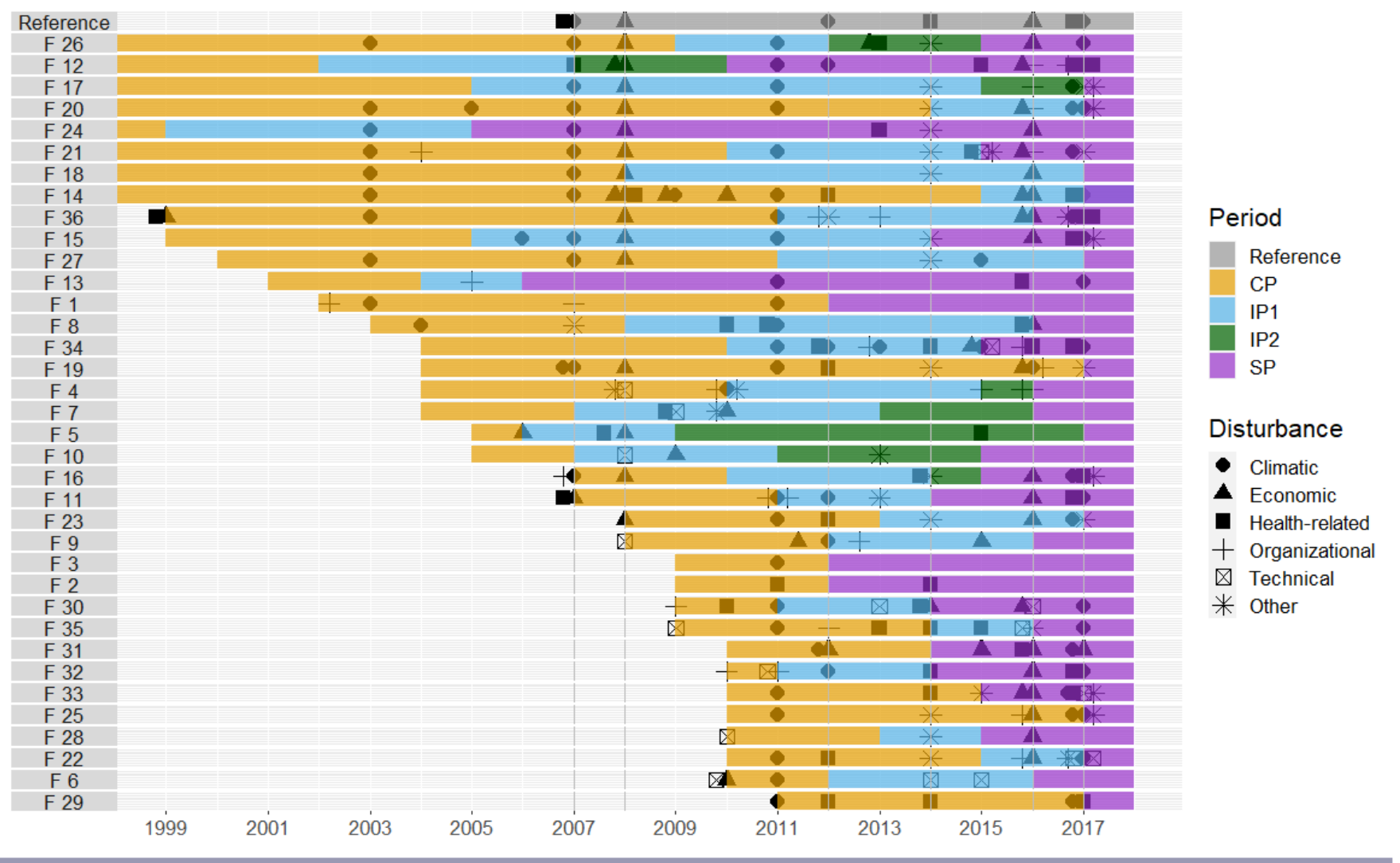

sPLS, which selects variables by introducing LASSO penalization (Lê Cao et al. 2008), improved the quality of the models. The PLS and sPLS enabled us to assess the dynamic aspect of the evolution of farm structure and farmers' practices over time (i.e., more than 5 years) and relate it to the evolution of the proxy of resilience.

\section{RESULTS}

Farm Trajectories in a Disturbed Context

Farmers in the sample identified two to four stable periods that lasted 1-25 years each over a 5- to 33-year timeframe (Fig. 4). For each farm, the first stable period included the conversion to organic (Conversion Period (CP)), as the retrospective survey started on the conversion date, and the last stable period ended in winter 2017-2018, the time of the survey (Survey Period (SP)). If necessary, farmers identified up to two intermediate periods (IP1 and IP2, respectively) between the CP and SP. Farms had to respond to a variety of disturbances over this long timeframe. Disturbances that farmers had experienced during the 10 years preceding the survey were compared with those reported by advisers, which were used as a reference. The type of disturbance mentioned most often ( 80 times) was climatic. Summer droughts in Aveyron had been severe during the previous 20 years, and farmers considered those in 2003 (9), 2007 (12), 2011 (21), and 2017 (23) as major disturbances. The drought in 2017 concerned mainly farms in southern Aveyron and had been compounded by late frosts that damaged lucerne fields. The second-most mentioned type of disturbance was economic (57), particularly two main events: the global economic crisis in 2008 (17) and delays in common agricultural policy payments in 2016 (24). The thirdmost mentioned disturbance was related to flock health (46), which were most frequent in 2017 (13) due to predation by wolves in plateau areas. As organizational and technical disturbances are components of the daily management of farms, they were mentioned consistently among years and stable periods. For the 36 farms, one stable period changed to another 72 times, and most changes $(60 \%)$ did not coincide with disturbances. For the remaining $40 \%$ of changes, most $(62 \%)$ coincided with a combination of two or more disturbances.

\section{Evolution of Farmers' Overall Satisfaction in a Disturbed Context}

During the SP, farmers' overall satisfaction was high, with a mean ( \pm 1 standard deviation) score of $11.96 \pm 1.69$ (out of 16 ) at the survey period (Fig $5 a$ ). In addition, 25 of those farms had a score $\geq 12$ (i.e., high satisfaction with the overall situation) in the same period. The mean evolution of overall satisfaction from the CP to $\mathrm{SP}$ was positive but variable: $0.11 \pm 0.26 /$ year. After the $\mathrm{CP}$, overall satisfaction increased on the majority of farms (20 out of 36) after the conversion period (Fig. $5 b$ ). Overall satisfaction decreased for eight farms $(-0.34$ to -0.03 for the value of the evolution of overall satisfaction). The remaining eight farms 
Fig. 5. (a) Mean overall satisfaction during the four stable periods (CP: conversion period, IP1: intermediate period 1, IP2: intermediate period 2, SP: survey period) identified by farmers. (b) Distribution of the evolution of overall satisfaction from the CP to SP for the 36 farms. The red line separates farmers with increased satisfaction from those with decreased satisfaction. (c) Relative contribution of the evolution of farmers' satisfaction with land, animals, economics, and social situation to the evolution of overall satisfaction.

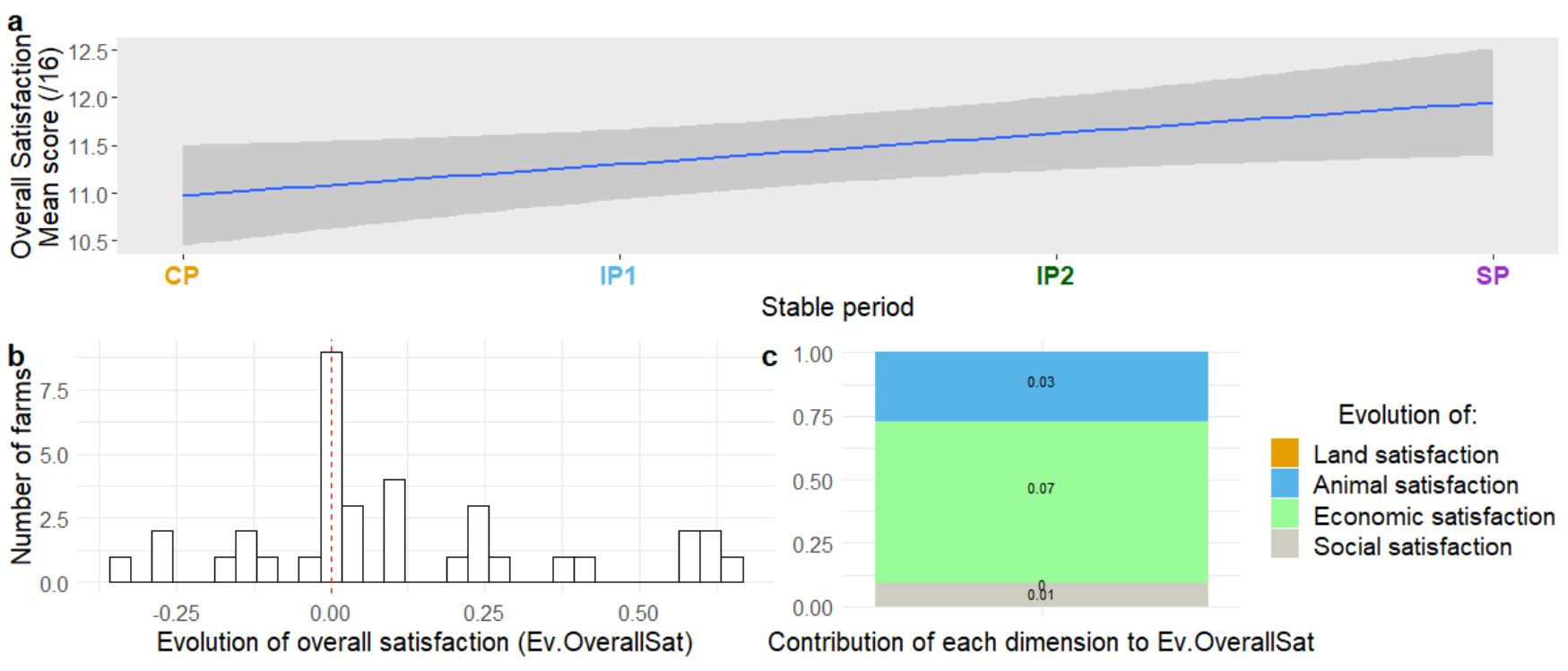

maintained the same level of overall satisfaction over time (i.e., presented a null value for the evolution of farmers' overall satisfaction). Evolution in the economic, animal, social, and land dimensions of satisfaction differed in their contributions to the mean evolution of overall satisfaction $(64 \%, 27 \%, 9 \%$, and $0 \%$, respectively) (Fig. 5c).

\section{Evolution of the structure, size, and practices of organic dairy sheep farms}

For farm structure, the number of ewes increased in 19 farms (Table 3), remained the same in nine farms, and decreased in eight farms. Across the 19 farms that increased their number of ewes, the increase was on average by $20.2 \pm 23.1$ ewes/year. Two farms drove the increase in both mean and variability because their farmers purchased a second farm and merged a second flock into the first one in the SP. The number of LU also tended to increase, but the number of permanent workers tended to remain the same, which resulted in an increasing trend in LU per worker. The UAA increased on 21 farms (maximum $=+36.3$ ha/year) and remained the same on 14 farms. As increases in UAA and flock size were proportional, the mean stocking rate remained the same $(0.00$ $\pm 0.02 \mathrm{LU} / \mathrm{ha} /$ year). The workload per hectare also tended to increase.

For farming practices, the mean duration of the grazing period decreased slightly (-0.04 months/year), but it was driven by five farms that shortened their grazing period the most ( -0.60 months/ year). The duration of the grazing period remained the same on most farms (29/36) and increased on only two farms. The start date of lambing remained the same on 16 farms, was advanced on 14 farms, and was delayed on six farms. Concentrate-use efficiency differed more among farms. After conversion, 21 farmers decreased the mean amount of concentrates distributed to ewes (by $-115.5 \mathrm{~g} / \mathrm{L}$ milk/year), five farmers provided the same
Table 3. Evolution of variables related to farm structure and size and agricultural practices.

\begin{tabular}{lccc}
\hline \hline & \multicolumn{2}{c}{$\begin{array}{c}\text { Number of farms concerned by the } \\
\text { evolution }\end{array}$} \\
\cline { 2 - 4 } & Increase & Decrease & Stability \\
\hline $\begin{array}{l}\text { Variable } \\
\text { Herd size }\end{array}$ & 19 & 8 & 9 \\
$\begin{array}{l}\text { Number of ewes/year) } \\
\text { (LUmber of livestock units }\end{array}$ & 19 & 8 & 9 \\
$\begin{array}{l}\text { Number of ewes per work unit } \\
\text { (Ewes/work unit/year) }\end{array}$ & 22 & 11 & 3 \\
$\begin{array}{l}\text { Utilized agricultural area } \\
\text { (ha/year) }\end{array}$ & 21 & 1 & 14 \\
$\begin{array}{l}\text { Number of hectares per work unit } \\
\text { (ha/work unit/year) }\end{array}$ & 22 & 7 & 7 \\
$\begin{array}{l}\text { Starting day of lambing } \\
\text { (Day of year/year) }\end{array}$ & 6 & 14 & 16 \\
$\begin{array}{l}\text { Concentrate use efficiency } \\
\text { g/L/year) }\end{array}$ & 10 & 21 & 5 \\
$\begin{array}{l}\text { Ewe productivity } \\
\text { (L milk/year) }\end{array}$ & 27 & 5 & 4 \\
\hline
\end{tabular}

amount, and the remaining 10 farmers increased this amount. The mean evolution of concentrate use efficiency thus decreased but remained highly variable $(-11.8 \pm 23.6 \mathrm{~g} / \mathrm{L}$ milk/year $)$. This trend had little influence, however, on the large amount of concentrates distributed in this context, which reached a mean of $564 \pm 263 \mathrm{~g} / \mathrm{L}$ milk/year during the SP. Ewe productivity increased on 27 farms, remained the same on four farms, and decreased on five farms. Mean ewe productivity thus increased by $4.5 \pm 5.6 \mathrm{~L}$ milk/ewe/year. 
Driving Factors that Influenced Overall Satisfaction of Organic Dairy Sheep Farmers

The sPLS model with the highest and most stable quality on component 1 (i.e., $\mathrm{Q}^{2}>$ the ad hoc threshold of $0.0975 ; \mathrm{R}^{2}=0.27$, the highest obtained) predicted the evolution of overall satisfaction mainly with three explanatory variables: estimated overall satisfaction during the CP (i.e., the intercept predicted by the model), the evolution of ewe productivity and the evolution of the duration of the grazing period (association scores of -0.59 , 0.52 , and -0.47 , respectively) (Fig. 6). Thus, increasing ewe productivity and decreasing the duration of grazing increased overall satisfaction in our sample.

Fig. 6. Results of the sparse partial least squared analysis. (Top) Projection of all variables. (Bottom) Network representing the strongest associations between the evolution of farmers' overall satisfaction ("Ev.OverallSat") and explanatory variables. Gray lines show negative associations, and the magenta line shows a positive association. See Table 2 for variable names and definitions.

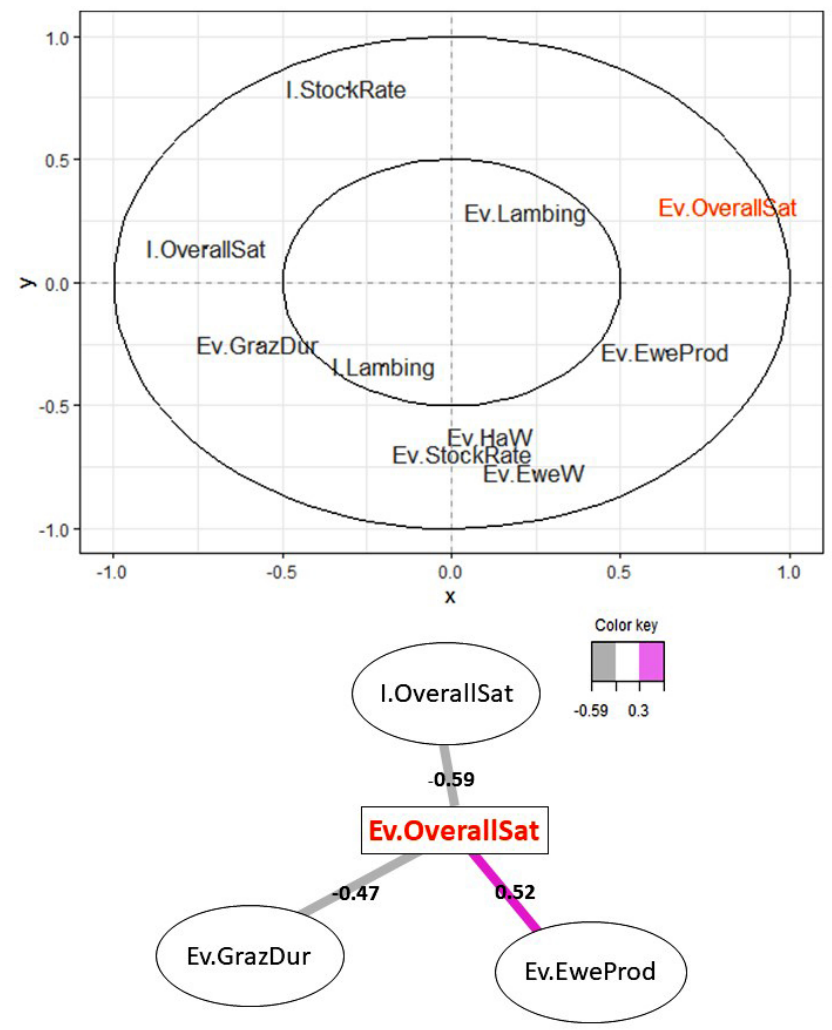

\section{Examples of Farms that Followed the Trends}

As an illustration of these results, farmers' overall satisfaction increased the most (+0.65/year) for F31, after starting at a high estimated level during the $\mathrm{CP}$ (10.58) (Table 4). This increase was related to a larger increase in ewe productivity than the sample's mean increase (+18.46 and $+4.55 \mathrm{~L}$ milk/ewe/year, respectively) and a larger decrease in the duration of the grazing period than the sample's mean decrease $(-0.29$ and -0.04 months/year, respectively). This is characteristic of the main results of the sPLS.
In contrast, overall satisfaction decreased (-0.15/year) for F21, despite starting at a high level during the CP (12.56). Ewe productivity decreased $(-2.89 \mathrm{~L}$ milk/ewe/year), unlike the mean increase for the sample. The duration of its grazing period was long (8.00 months) and remained the same over time.

Table 4. Values of the three variables - estimated overall satisfaction during the conversion period (I. OverallSat), evolution of ewe productivity (Ev.EweProd), and evolution of the duration of the grazing period (Ev.GrazDur) - most strongly associated with the evolution of farmers' overall satisfaction (Ev. OverallSat) for two contrasting farms, compared with the mean of the sample $(\bar{x})$. The symbols “-”, “, , and “ $\searrow$ " indicate that the variable remained the same over time, increased more than the sample's mean increase or decreased more than the sample's mean decrease, respectively.

\begin{tabular}{llllll}
\hline \hline Variable & F31 & & F21 & & $\overline{\mathrm{x}}$ \\
\hline Ev.OverallSat (score out of 16/ & 0.65 & $\nearrow$ & -0.15 & $\searrow$ & 0.11 \\
year) & & & & & \\
I.OverallSat (score out of 16) & 10.58 & & 12.56 & & 11.16 \\
Ev.EweProd (L milk/ewe/year) & 18.46 & $\nearrow$ & -2.89 & $\searrow$ & 4.55 \\
Ev.GrazDur (months/year) & -0.29 & $\searrow$ & 0.00 & - & -0.04 \\
\hline
\end{tabular}

\section{Alternative Models: Counter Examples}

Overall, the results showed an increasing trend in farm size (i.e., ewes, LU, and UAA) and a relationship between increasing ewe productivity and overall satisfaction. However, three farms did not follow this trend completely. On F2, F9, and F13, the number of ewes decreased (-6.7, -4.8, and -20.0/year, respectively), and ewe productivity decreased on F2 and F9 but increased on F13 $(+4.0 /$ year $)$. For all three farms, the decrease in the number of ewes was a direct consequence of the farmers' strategies. When these farmers divided their farms' histories into stable periods, they specified that the main objectives that had guided their management decisions included "simplifying the system," "having free time," "reducing flock size while producing a living for three households." As a result, these evolutions resulted in an increase in overall satisfaction (which increased from 9/16 to 14/16 from CP to SP for both F2 and F9) or a slight decrease in an already high overall satisfaction (from 13 to 12 for F13).

\section{DISCUSSION}

Advantages and Disadvantages of Using Farmers' Satisfaction to Assess Subjective Resilience

Our study is the first to relate the evolution of subjective farm resilience to changes in farm structure and farming practices on organic dairy sheep farms in France and to identify driving factors behind this subjective resilience. Farmers' overall satisfaction was used to provide subjectivity to the resilience assessment, which has been a major disadvantage of resilience assessments to date (Jones 2019). Estimating overall satisfaction as the sum of individual satisfaction with their land, flock, economics, and social situation enabled the farm to be considered in a holistic manner, with its diversity of subsystems and performances (Darnhofer et al. 2012). Using slope to characterize the evolution of explanatory and response variables over long timeframes addressed the dynamic aspect of resilience, as required in any 
resilience assessment (Carpenter et al. 2001). The wide timeframes defined by our sampling protocol (at least 5 years under organic farming) smoothed situational biases and avoided an overly positive assessment of non-resilient farms. A farmer may have overestimated his/her level of satisfaction for a given period, but if difficulties persisted, they would have emerged in the long term and been reflected in the evolution of overall satisfaction.

Nevertheless, our results should be interpreted and generalized with caution. Assessing resilience remains a complex task (Quinlan et al. 2016), and using a single indicator based on farmers' remembered levels of satisfaction resulted in some cognitive biases:

1. Recall bias can occur when respondents provide their own retrospective information (Raphael 1987). It is a major threat to the internal validity of studies that use self-reported data, and much of the information can be lost in memories more than 5 years old (Hassan 2005). Identifying stable periods sometimes several decades in the past (the earliest conversion in our sample was in 1984) and rating satisfaction scores for these older periods may have resulted in bias due to over- or under-scoring satisfaction levels.

2. Farmers were informed in advance about the purpose of the survey, which may have generated a subjective bias. Farmers may have interpreted survey questions in the context of their general perception and knowledge of farm resilience, and implicitly tried to meet their perceptions of interviewers' expectations (Bradburn et al. 1989), such as by forcing an increase in satisfaction to demonstrate progress. The focus on farmers' satisfaction may have ignored other key aspects, such as ecological decline within the agroecosystems (Armitage et al. 2012). In addition, no objective measurements exist for satisfaction with land, animals, economics, or social situation that could confirm the trends we observed. As Allen et al. (2018) suggested, additional quantitative assessment using indicators such as the evolution of soil organic matter content would help estimate this knowledge gap and the eventual loss of resilience, especially if conducted on slow variables (Biggs et al. 2012).

3. The favorable production context (organic milk production in a PDO area) may have introduced an "optimistic bias" when farmers assessed their satisfaction during the SP. Risk perception is a pillar of social resilience (Bradford et al. 2012) and is influenced directly by overconfidence or an illusion of control (Simon et al. 1999). The favorable context may have made some farmers overconfident to the point that they ignored that sudden changes could still occur. This is best illustrated by the predominance of economic satisfaction in the evolution of farm resilience perceived by farmers.

\section{Risks of Conventionalization of Organic Dairy Sheep Farms Overlooked when Using Farmers' Satisfaction to Assess Subjective Farm Resilience}

The driving factors of subjective farm resilience assessed via farmers' satisfaction we identified highlighted an orientation of organic sheep milk production toward a form of conventionalization, with organic farming becoming a slightly modified version of modern conventional agriculture (De Wit and Verhoog 2007). This phenomenon is highlighted among other things by the specialization of farms and the intensification of production (Guthman 2004), which generally implies increased reliance on off-farm inputs, e.g., livestock feed. We observed a dominant trend toward an increase in ewe productivity and a high consumption of concentrates per L milk and a sharp decrease in the duration of the grazing period on a few farms. For example, on the one hand, F31 experienced the largest increase in farmer overall satisfaction, but on the other hand, it consumed a lot more concentrates per L of milk compared with a network of French organic sheep farms (336 and $223 \mathrm{~g} / \mathrm{L}$ milk, respectively; De Boissieu et al. 2018) although productivity levels were also higher. Further increases in ewe productivity would require breeding progress and increasing the energy and protein density of the ewe diet, which is eased by distributing concentrates. Thus, this productivity paradigm could progressively promote increased dependence on feed inputs in organic sheep milk production, which was clearly identified as an indicator of conventionalization of organic animal production (Darnhofer et al. 2010). Conventionalization was also evident in flock management. The starting date of lambing (the fourth-strongest variable associated with the evolution of overall satisfaction on SPLS component 1; see Append. 2) was progressively advanced and moved away from the "natural" behavior of ewes. Some sheep farmers implemented that practice to produce more milk outside the "natural" milking season to obtain higher milk prices. The consequence is a lengthening of the indoor feeding period, which has the highest rate of concentrate distribution to compensate for hay's lower feed value compared with grazed pasture. The three farms that had followed alternative pathways to the increasing trend in farm size (i.e., ewes, LU, and UAA) did not differ much from the general trend regarding agricultural practices with, e.g., the duration of grazing decreasing on one farm and remaining stable on the two others. Conventionalization thus appears as an indirect outcome of driving factors that lead to higher farmers' satisfaction.

Given these facts, using farmers' satisfaction as a proxy of subjective farm resilience might incompletely reflect the longterm resilience of farms as social-ecological systems; identified driving factors of satisfaction are sometimes at odds with indicators and factors of social-ecological resilience previously reported in the literature. Practices compromising a responsible use of local resources are at odds with the resilience indicators "Coupled with local natural capital" and "Globally autonomous and locally interdependent" proposed by Cabell and Oelofse (2012). Increasing ewe productivity and feed distribution in stalls while remaining highly reliant on purchased concentrates and decreasing the use of pasture corresponds to what Darnhofer et al. (2016) called the "pathology of "command and control"", which is identified as a threat to farm resilience. Shortening the grazing period, which often occurs when pastures are used less often, changes how urine and manure are spread on a farm and thus increases imbalances in soil fertility among farm fields. In the long term, it decreases a farm's ability to ecologically selfregulate (Cabell and Oelofse 2012). A shorter grazing period can also encourage woody plants to encroach on areas that are suitable only for grazing, which are then abandoned to focus on producing feed in the most productive pastures. This process can degrade the traditional legacy of landscape management in Aveyron (Cabell and Oelofse 2012). Although dairy intensification and higher productivity and efficiency can increase income, they have 
social and environmental costs (Clay et al. 2019) In the long term, the trend toward conventionalization and the related productivity paradigm could affect farms' ability to cope with shocks, as observed by Sinclair et al. (2014) for dairy cattle farms. This calls for caution when using farmers' satisfaction as a proxy of subjective farm resilience.

\section{Implications}

Using the evolution of farmers' overall satisfaction as a proxy for farm resilience allowed us to focus on the subjective dimension of resilience and highlight its driving factors, mainly increasing ewe productivity and reducing the duration of the grazing season, enabling organic dairy sheep farms to cope with a variety of disturbances. We also identified biases in the use of this resilience proxy. The emphasis on subjectivity in a particular context of high-priced agricultural products might induce optimistic biases. Using satisfaction might also overlook the long-term resilience of the social-ecological systems that farms are. Satisfaction as a proxy for resilience also highlighted contradictions between farmers' discourse and the evolution of practices implemented on the farms. In a sample of 128 farms (including the 36 farms in the present study), we observed that farmers identified the search for autonomy, the reduction of pressure on farm resources, and the search for diversity as resilience factors (Perrin et al. 2020b). The context of high milk prices and the observed evolution of agricultural practices on organic dairy sheep farms in Aveyron did not match those assertions. Thus, assessing farm resilience based on the evolution of farmers' satisfaction requires caution in interpreting the results. Long-term subjective assessments should be supplemented with more objective long-term monitoring of slow variables that reflect farm resilience (e.g., soil organic matter content, flock genetic potential against drought, parasite and disease outbreaks, farmers' knowledge).

The driving factors increasing subjective resilience highlighted in this study are relatively specific to French dairy sheep farms in a context of high milk prices due to organic and PDO certification. These results may not be relevant for European countries with lower milk prices, such as Greece or Spain. Nevertheless, these findings reflect the trend of conventionalization of the organic sector observed outside of France (Ramos García et al. 2018) and can raise concrete policy issues. Sensitizing farmers to resilience issues that result from this conventionalization should be on the political agenda in rural regions where maintaining agricultural activities is a concern.

\section{Responses to this article can be read online at:}

https://www.ecologyandsociety.org/issues/responses. php/12583

\section{Acknowledgments:}

We thank the farmers for welcoming us to their farms and taking the time to answer our questions. This study was funded by the French Ministry of Research (Ph.D. fellowship of A.P.) and the Résilait project. We thank Alexandre Bancarel, Stéphane Doumayzel, Mathilde Durand, Olivier Patout, Camille Andrieu, and the groups of students coordinated by Séverine Cassel for conducting the interviews. We also thank Catherine Experton and Jerôme Pavie as Résilait project leaders.

\section{Data Availability:}

The datalcode that support the findings of this study are available on request from the corresponding author, [A.P]. The datalcode are not publicly available as they contain information that could compromise the privacy of research participants. A part of the code and of the statistical analysis that support the findings of this study are available in the 'supplementary materials'

\section{LITERATURE CITED}

Adger, W. N. 2006. Vulnerability. Global Environmental Change 16(3):268-281. https://doi.org/10.1016/j.gloenvcha.2006.02.006

Agence Bio. 2018. Aller plus loin: Les données brutes, données départementales. In "Les chiffres clés." Agence Bio, Paris, France. [online] URL: https://www.agencebio.org/vos-outils/les-chiffrescles/

Allen, C. R., H. E. Birge, D. G. Angeler, C. A. Arnold, B. C. Chaffin, D. A. DeCaro, A. S. Garmestani, and L. Gunderson. 2018. Quantifying uncertainty and trade-offs in resilience assessments. Ecology and Society 23(1): 3. https://doi. org/10.5751/ES-09920-230103

Armitage, D., C. Béné, A. T. Charles, D. Johnson, and E. H. Allison. 2012. The interplay of well-being and resilience in applying a social-ecological perspective. Ecology and Society 17 (4): 15. https://doi.org/10.5751/ES-04940-170415

Ballesteros, S. 2008. Le modèle linéaire avec R : fonction $\operatorname{lm}()$. Muséum national d'histoire naturelle, Paris, France. [online] URL: https://rug.mnhn.fr/semin-r/PDF/semin-R_Im_SBallesteros_110308. pdf

Biggs, R., M. Schlüter, D. Biggs, E. L. Bohensky, S. BurnSilver, G. Cundill, V. Dakos, T. M. Daw, L. S. Evans, K. Kotschy, A. M. Leitch, C. Meek, A. Quinlan, C. Raudsepp-Hearne, M. D. Robards, M. L. Schoon, L. Schultz, and P. C. West. 2012. Toward principles for enhancing the resilience of ecosystem services. Annual Review of Environment and Resources 37(1):421-448. https://doi.org/10.1146/annurev-environ-051211-123836

Boffet, L. 2017. Le roquefort n'est plus le bienvenu en Chine. Franceinfo: 3 occitanie. [online] URL: https://france3-regions. francetvinfo.fr/occitanie/aveyron/rodez/roquefort-n-est-plus-bienvenuchine-1325557.html

Bouttes, M., N. Bize, G. Maréchal, G. Michel, M. S. Cristobal, and G. Martin. 2019. Conversion to organic farming decreases the vulnerability of dairy farms. Agronomy for Sustainable Development 39(2): 19. https://doi.org/10.1007/s13593-019-0565-3

Bradburn, N. M., L. J. Rips, and S. K. Shevell. 1989. Answering autobiographical questions: the impact of memory and inference on surveys. Science 236(4798):157-161. https://doi.org/10.1126/ science. 3563494

Bradford, R. A., J. J. O’Sullivan, I. M. van der Craats, J. Krywkow, P. Rotko, J. Aaltonen, M. Bonaiuto, S. De Dominicis, K. Waylen, 
and K. Schelfaut. 2012. Risk perception-issues for flood management in Europe. Natural Hazards and Earth System Sciences 12(7):2299-2309. https://doi.org/10.5194/nhess-12-2299-2012

Cabell, J. F., and M. Oelofse. 2012. An indicator framework for assessing agroecosystem resilience. Ecology and Society 17(1): 18. https://doi.org/10.5751/ES-04666-170118

Caracciolo, F., G. Cicia, T. Del Giudice, L. Cembalo, A. Krystallis, K. G. Grunert, and P. Lombardi. 2016. Human values and preferences for cleaner livestock production. Journal of Cleaner Production 112:121-130. https://doi.org/10.1016/j. jclepro.2015.06.045

Carpenter, S. R., F. Westley, and M. G. Turner. 2005. Surrogates for resilience of social-ecological systems. Ecosystems 8 (8):941-944. https://doi.org/10.1007/s10021-005-0170-y

Carpenter, S., B. Walker, J. M. Anderies, and N. Abel. 2001. From metaphor to measurement: resilience of what to what? Ecosystems 4(8):765-781. https://doi.org/10.1007/s10021-001-0045-9

Clay, N., T. Garnett, and J. Lorimer. 2019. Dairy intensification: drivers, impacts and alternatives. Ambio 49:35-48. https://doi. org/10.1007/s13280-019-01177-y

Cohn, M. A., B. L. Fredrickson, S. L. Brown, J. A. Mikels, and A. M. Conway. 2009. Happiness unpacked: positive emotions increase life satisfaction by building resilience. Emotion 9 (3):361-368. https://doi.org/10.1037/a0015952

Cumming, G. S., G. Barnes, S. Perz, M. Schmink, K. E. Sieving, J. Southworth, M. Binford, R. D. Holt, C. Stickler, and T. Van Holt. 2005. An exploratory framework for the empirical measurement of resilience. Ecosystems 8(8):975-987.

Darnhofer, I. 2014. Resilience and why it matters for farm management. European Review of Agricultural Economics 41 (3):461-484. https://doi.org/10.1093/erae/jbu012

Darnhofer, I., D. Gibbon, and B. Dedieu. 2012. Farming systems research: an approach to inquiry. Pages 3-31 in I. Darnhofer, D. Gibbon, and B. Dedieu, editors. Farming systems research into the 21st century: the new dynamic. Springer Netherlands, Dordrecht, The Netherlands. https://doi.org/10.1007/978-94-007-4503-2_1

Darnhofer, I., T. Lindenthal, R. Bartel-Kratochvil, and W. Zollitsch. 2010. Conventionalisation of organic farming practices: from structural criteria towards an assessment based on organic principles. A review. Agronomy for Sustainable Development 30(1):67-81. https://doi.org/10.1007/978-94-007-0394-0_18

Davoudi, S., K. Shaw, L. J. Haider, A. E. Quinlan, G. D. Peterson, C. Wilkinson, H. Fünfgeld, D. McEvoy, L. Porter, and S. Davoudi. (Davoudi, S., and L. Porter, editors.) 2012. Resilience: a bridging concept or a dead end? "Reframing" resilience: challenges for planning theory and practice. Interacting traps: resilience assessment of a pasture management system in northern Afghanistan. Urban resilience: what does it mean in planning practice? Resilience as a useful concept for climate change adaptation? The politics of resilience for planning: a cautionary note. Planning Theory and Practice 13(2):299-333. https://doi. org/10.1080/14649357.2012.677124
De Boissieu, C., E. Morin, O. Patout, T. Taurignan, N. Rivemale, L. Drochon, S. Doumayzel, and G. Noubel. 2020. Les exploitations ovines laitières du massif central en agriculture biologique. Résultats campagne 2018. Collectif BioRéférences et Pôle AB massif central, Lempdes, France.

De Boissieu, C., O. Patout, N. Rivemale, L. Drochon, S. Doumayzel, and G. Noubel. 2018. Les exploitations ovines laitières du massif central en agriculture biologique. Résultats campagne 2016. Collectif BioRéférences. Pôle AB massif central et Pôle AB Massif central, Lempdes, France.

Dedieu, B., and S. Ingrand. 2010. Incertitude et adaptation : cadres théoriques et application à l'analyse de la dynamique des systèmes d'élevage. INRAE Productions Animales 23(1): 81-90.

De Wit, J., and H. Verhoog. 2007. Organic values and the conventionalization of organic agriculture. NJAS - Wageningen Journal of Life Sciences 54(4):449-462. https://doi.org/10.1016/ $\underline{\text { S1573-5214(07)80015-7 }}$

Diserens, F., J. Choptiany, D. Barjolle, B. Graeub, C. Durand, and J. Six. 2018. Resilience assessment of Swiss farming systems: piloting the SHARP-Tool in Vaud. Sustainability 10(12):4435. https://doi.org/10.3390/su10124435

Dumont, B., L. Puillet, G. Martin, D. Savietto, J. Aubin, S. Ingrand, V. Niderkorn, L. Steinmetz, and M. Thomas. 2020. Incorporating diversity into animal production systems can increase their performance and strengthen their resilience. Frontiers in Sustainable Food Systems 4: 109. https://doi. org/10.3389/fsufs. 2020.00109

European Commission. 2019. Agri-environmental indicatorlivestock patterns. Statistics explained. Eurostat, Luxembourg City, Luxembourg.

Eurostat. 2017a. Eurostat statistics explained. Glossary utilised agricultural area (UAA). Eurostat, Luxembourg City, Luxembourg.

Eurostat. 2017b. Eurostat statistics explained. Glossary livestock unit (LSU). Eurostat, Luxembourg City, Luxembourg.

FranceAgriMer. 2020. Données économiques, agricoles et alimentaires. Enquête mensuelle laitière. Lait de Brebis. FranceAgriMer, Libourne, Montreuil, Volx, France.

Garrido, A. 2016. Agricultural markets instability: revisiting the recent food crises. Routledge, London, UK. https://doi. org/10.4324/9781315676265

Gauly, M., H. Bollwein, G. Breves, K. Brügemann, S. Dänicke, G. Daş, J. Demeler, H. Hansen, J. Isselstein, S. König, M. Lohölter, M. Martinsohn, U. Meyer, M. Potthoff, C. Sanker, B. Schröder, N. Wrage, B. Meibaum, G. von Samson-Himmelstjerna, H. Stinshoff, and C. Wrenzycki. 2013. Future consequences and challenges for dairy cow production systems arising from climate change in Central Europe-a review. Animal 7(05):843-859. https://doi.org/10.1017/s1751731112002352

Green, F. 2010. Well-being, job satisfaction and labour mobility. Labour Economics 17(6):897-903. https://doi.org/10.1016/j. $\underline{\text { labeco.2010.04.002 }}$ 
Greenhill, J., D. King, A. Lane, and C. MacDougall. 2009. Understanding resilience In South Australian farm families. Rural Society 19(4):318-325. https://doi.org/10.5172/rsj.351.19.4.318

Groot, J., J. Cortez-Arriola, W. Rossing, R. Améndola Massiotti, and P. Tittonell. 2016. Capturing agroecosystem vulnerability and resilience. Sustainability 8(11): 1206. https://doi.org/10.3390/ su8111206

Guthman, J. 2004. The trouble with "organic lite" in California: a rejoinder to the "conventionalisation" debate. Sociologia Ruralis 44(3):301-316. https://doi.org/10.1111/j.1467-9523.2004.00277. $\underline{\mathrm{X}}$

Hassan, E. 2005. Recall bias can be a threat to retrospective and prospective research designs. Internet Journal of Epidemiology 3: 2 .

Heiberg, E. J., and K. L. Syse. 2020. Farming autonomy: Canadian beef farmers reclaiming the grass through management-intensive grazing practices. Organic Agriculture 10:471-486. https://doi.org/10.1007/s13165-020-00291-6

Institut de l'élevage (IDELE). 2018. Les chiffres clés du GEB. Ovins 2018. Productions de lait et de viande. Institut de l'élevage, Laxou, France.

Institut de l'agriculture et de l'alimentation biologiques (ITAB). 2017. RESILAIT : Résilience des systèmes laitiers biologiques; optimisation des facteurs de compétitivité et mise au point de systèmes plus efficients dans la gestion des risques à venir. Institut technique national dédié à la recherche en agriculture biologique. ITAB, France. [online] URL: http://www.itab.asso.fr/programmes/ resilait.php

Jones, L. 2019. Resilience isn't the same for all: comparing subjective and objective approaches to resilience measurement. Wiley Interdisciplinary Reviews: Climate Change 10(1): e552. https://doi.org/10.1002/wcc.552

Jones, L., and T. Tanner. 2017. "Subjective resilience": using perceptions to quantify household resilience to climate extremes and disasters. Regional Environmental Change 17(1):229-243. https://doi.org/10.1007/s10113-016-0995-2

Kaseva, J., S. J. Himanen, and H. Kahiluoto. 2019. Managing diversity for food system resilience. Pages 1-32 in D. Barling, editor. Advances in food security and sustainability. Elsevier, Cambridge, Massachusetts, USA; London, UK. https://doi. org/10.1016/bs.af2s.2019.07.001

Krosnick, J. A., A. L. Holbrook, M. K. Berent, R. T. Carson, W. M. Hanemann, R. J. Kopp, R. C. Mitchell, S. Presser, P. A. Ruud, V. K. Smith, W. R. Moody, M. C. Green, and M. Conaway. 2001. The impact of "no opinion" response options on data quality. Public Opinion Quarterly 66(3):371-403. https://doi.org/10.1086/341394

Lê Cao, K.-A., D. Rossouw, C. Robert-Granié, and P. Besse. 2008. A sparse PLS for variable selection when integrating omics data. Statistical Applications in Genetics and Molecular Biology 7(1): 35. https://doi.org/10.2202/1544-6115.1390

Li, M., C. A. Peterson, N. E. Tautges, K. M. Scow, and A. C. M. Gaudin. 2019. Yields and resilience outcomes of organic, cover crop, and conventional practices in a Mediterranean climate. Scientific Reports 9(1): 12283. https://doi.org/10.1038/s41598-019-48747-4

Martin, G., M.-A. Magne, and M. San Cristobal. 2017. An integrated method to analyze farm vulnerability to climatic and economic variability according to farm configurations and farmers' adaptations. Frontiers in Plant Science 8: 1483. https:// doi.org/10.3389/fpls.2017.01483

Maucorps, A., A. Münch, S. Brkanovic, and B. Schuh. 2019. The EU farming employment: current challenges and future prospects. European Parliament, Policy Department for Structural and Cohesion Policies, Brussels, Belgium.

Meuwissen, M., W. Paas, T. Slijper, I. Coopmans, A. Ciechomska, J. Deckers, W. Vroege, E. Mathijs, B. Kopainsky, H. Herrera, R. Finger, Y. D. Mey, P. M. Poortvliet, P. Nicholas-Davies, M. Vigani, D. Maye, J. Urquhart, A. Balmann, F. Appel, K. Termeer, P. Feindt, J. Candel, M. Tichit, F. Accatino, S. Senni, E. Wauters, I. Bardají, B. Soriano, C.-J. Lagerkvist, G. Manevska-Tasevska, H. Hansson, C. Gavrilescu, and P. Reidsma. 2020. Report on resilience framework for EU agriculture Work Performed by P1 (WU) in cooperation with all partners. SURE-Farm, Wageningen, The Netherlands. [online] URL: https://www. surefarmproject.eu/wordpress/wp-content/uploads/2018/02/SUREFarm Deliverable-D1.1-Resilience-Framework.pdf

Milestad, R., and I. Darnhofer. 2003. Building farm resilience: the prospects and challenges of organic farming. Journal of Sustainable Agriculture 22(3):81-97. https://doi.org/10.1300/ J064v22n0309

Moulin, C.-H., S. Ingrand, J. Lasseur, S. Madelrieux, M. Napoléone, J. Pluvinage, and V. Thénard. 2008. Comprendre et analyser les changements d'organisation et de conduite de l'élevage dans un ensemble d'exploitations : propositions méthodologiques. Pages 181-196 in B. Dedieu, E. Chia, B. Leclerc, C. H. Moulin, and M. Tichit, editors. L'élevage en mouvement : flexibilité et adaptation des exploitations d'herbivores, Editions Quae, Versailles, France.

Olesen, J. E., and M. Bindi. 2002. Consequences of climate change for European agricultural productivity, land use and policy. European Journal of Agronomy 16(4):239-262. https://doi. org/10.1016/S1161-0301(02)00004-7

Perrin, A., M. S. Cristobal, R. Milestad, and G. Martin. 2020a. Identification of resilience factors of organic dairy cattle farms. Agricultural Systems 183: 102875. https://doi.org/10.1016/j. agsy.2020.102875

Perrin, A., R. Milestad, and G. Martin. 2020b. Resilience applied to farming: organic farmers' perspectives. Ecology and Society 25(4): 5. https://doi.org/10.5751/es-11897-250405

Quinlan, A. E., M. Berbés-Blázquez, L. J. Haider, and G. D. Peterson. 2016. Measuring and assessing resilience: broadening understanding through multiple disciplinary perspectives. Journal of Applied Ecology 53(3):677-687. https://doi. org/10.1111/1365-2664.12550

Ramos García, M., G. I. Guzmán, and M. González De Molina. 2018. Dynamics of organic agriculture in Andalusia: moving toward conventionalization? Agroecology and Sustainable Food Systems 42(3):328-359. https://doi.org/10.1080/21683565.2017.1394415 
Raphael, K. 1987. Recall bias: a proposal for assessment and control. International Journal of Epidemiology 16(2):167-170. https://doi.org/10.1093/ije/16.2.167

Rojas-Downing, M. M., A. P. Nejadhashemi, T. Harrigan, and S. A. Woznicki. 2017. Climate change and livestock: impacts, adaptation, and mitigation. Climate Risk Management 16:145-163. https://doi.org/10.1016/j.crm.2017.02.001

Schulte, H. D., O. Musshoff, and M. P. M. Meuwissen. 2018. Considering milk price volatility for investment decisions on the farm level after European milk quota abolition. Journal of Dairy Science 101(8):7531-7539. https://doi.org/10.3168/jds.2017-14305

Simon, M., S. M. Houghton, and K. Aquino. 1999. Cognitive biases, risk perception, and venture formation: how individuals decide to start companies. Journal of Business Venturing 15 (2):113-134. https://doi.org/10.1016/s0883-9026(98)00003-2

Sinclair, K., A. Curtis, E. Mendham, and M. Mitchell. 2014. Can resilience thinking provide useful insights for those examining efforts to transform contemporary agriculture? Agriculture and Human Values 31(3):371-384. https://doi.org/10.1007/s10460-014-9488-4

Spelle, C., and C. Daudé. 2019. Chiffres clés 2017 des produits sous signes de la qualité et de l'origine. Produits laitiers AOP et IGP. Version corrigée de juin 2019. Institut National de l'Origine et de la Qualité (INAO), Paris, France.

Tenenhaus, M. 1998. La régression PLS: théorie et pratique. Editions Technip, Paris, France.

Toro-Mujica, P., A. García, A. G. Gómez-Castro, R. Acero, J. Perea, V. Rodríguez-Estévez, C. Aguilar, and R. Vera. 2011. Technical efficiency and viability of organic dairy sheep farming systems in a traditional area for sheep production in Spain. Small Ruminant Research 100(2-3):89-95. https://doi.org/10.1016/j. smallrumres.2011.06.008

Toro-Mujica, P., A. García, A. Gómez-Castro, J. Perea, V. Rodríguez-Estévez, E. Angón, and C. Barba. 2012. Organic dairy sheep farms in south-central Spain: typologies according to livestock management and economic variables. Small Ruminant Research 104(1-3):28-36. https://doi.org/10.1016/j.smallrumres.2011.11.005

Vial, M. 2017. État des lieux des fermes ovins lait bio en Aveyron. Fédération Nationale de l'Agriculture Biologique, France. [online] URL: https://www.produire-bio.fr/articles-pratiques/ etat-lieux-fermes-ovins-lait-bio-aveyron/https://doi.org/10.1016/ $\underline{\mathrm{s} 0992-5945(20) 30149-5}$

Walker, B., C. S. Holling, S. R. Carpenter, and A. P. Kinzig. 2004. Resilience, adaptability and transformability in social-ecological systems. Ecology and Society 9(2): 5. https://doi.org/10.5751/ ES-00650-090205 


\section{APPENDIX 1}

to Driving factors behind subjective resilience on organic dairy sheep farms

\section{Overview of the statistical analysis}

Initial dataset:

The following table presents the structure of the initial dataset. Each row contains the values for each variable, for each period identified on each farm.

\begin{tabular}{|l|l|l|l|l|l|l|}
\hline Farm code & Years & Period & Var1 & Var2 & $\ldots$ & OverallSat \\
\hline F1 & & CP & & & & \\
\hline F1 & & IP1 & & & & \\
\hline F1 & & IP2 & & & & \\
\hline F1 & & FP & & & & \\
\hline F2 & & CP & & & & \\
\hline F2 & & FP & & & & \\
\hline$\ldots$ & & & & & & \\
\hline F36 & & CP & & & & \\
\hline F36 & & FP & & & & \\
\hline
\end{tabular}

Table 1: Structure of the initial dataset. $\mathrm{CP}=$ Conversion Period, IP = Intermediate Period, $\mathrm{SP}=$ Survey Period, Var $=$ Variable, OverallSat $=$ Overall Satisfaction 


\section{Calculation of slope and intercept values:}

By running a linear regression $(\operatorname{Im}()$ function from stats package in $\mathrm{R})$ throughout the stable periods available for each farm, the initial dataset is used to calculate the slope and intercept values for each variable and for each farm (i.e. 'Ev.+variable name' for slopes and 'I.+variable name' for intercepts).

These values are compiled in a table similar to the table below:

Values at the final period
\begin{tabular}{|l|l|l|l|l|l|l|l|l|l|l|l|l|l|}
\hline $\begin{array}{l}\text { Farm } \\
\text { code }\end{array}$ & Year & Period & Var1 & Var2 & $\ldots$ & OverallSat & Ev.Var1 & $\ldots$ & Ev.OverallSat & I.Var1 & $\ldots$ & I.OverallSat \\
\hline F1 & & FP & & & & & & & & & & \\
\hline F2 & & FP & & & & & & & & & & \\
\hline F3 & & FP & & & & & & & & & & \\
\hline$\ldots$ & & FP & & & & & & & & & & \\
\hline F35 & & FP & & & & & & & & & & \\
\hline F36 & & FP & & & & & & & & & & \\
\hline
\end{tabular}

Table 2: Dataset with final values slopes and intercepts for all variables. Var = Variable

\section{PLS and SPLS rounds}

The dataset with final values, slopes and intercepts is used for performing several rounds of PLS and SPLS using the mixOmics package in $\mathrm{R}$ ( $\mathrm{R}$ code available in Appendix $\mathrm{B}$ ).

PLS enables explaining and predicting response variable(s) (in our case variables illustrating farmers' satisfaction) from explanatory variables (in our case variables regarding farm structure and agricultural practices).

sPLS is always performed after one PLS to improve the model quality which is assessed through the Q2 value. 
to Driving factors behind subjective resilience on organic dairy sheep farms

by Augustine Perrin and Guillaume Martin

\section{Details on PLS, sPLS and main results}

This appendix details the R code used for performing PLS and SPLS.

A complete version of the $R$ code used for the statistical analysis is available upon request to the authors.

The following R code proposes one example for performing one PLS and one sPLS.

\section{R code. Example for PLS 1.1}

For this example, explanatory variables are slopes and intercepts and interest variables are the evolution of the four dimensions of farmers' satisfaction.

X=as.matrix(Data [, c("Ev.UAA", "Ev.AFL", "Ev.Crops", "Ev. Ewe", "Ev. EweProd", "Ev. Lambing", "Ev.Turnout", "Ev.GrazDur", "Ev.FullGrazDur", "Ev. GFeedDur", "Ev.ConcD ist", "Ev.LU", "Ev.Pastures", "Ev.StockRate", "Ev.SSFod", "Ev.SSConc", "Ev.WorkLU ", "Ev.WorkHa", "I.UAA", "I.AFL", "I.Crops", "I.Ewe", "I.EweProd", "I. Lambing" , "I. Turnout", "I.GrazDur", "I.FullGrazDur", "I.GFeedDur", "I.ConcDist", "I.LU", "I.Pa stures", "I.StockRate", "I.SSFod", "I.SSConc", "I.WorkLU", "I.WorkHa", "I. LandSat ", "I.AnimSat", "I.EconSat", "I.SociSat")])

\#X is the matrix with explanatory variables

Y=as.matrix (Data [, c("Ev.LandSat", "Ev.AnimSat", "Ev.EconSat", "Ev.SociSat") ]) $\# Y$ is the matrix with interest variables

pls $=\operatorname{pls}(X, Y, n c o m p=4$, mode="regression" $)$

\# We perform the PLS to explain and predict $\mathrm{Y}$ thanks to $\mathrm{X}$

$\operatorname{plotVar}(p l s, c e x=c(3.5,3.5)$, title $=" P L S 1.1 ")$

\# We plot variables to illustrate associations. The variables $X$ and $Y$ are $r$ epresented through their projections onto the plane defined either by $X$-var iates or $\mathrm{Y}$-variates. The variables $\mathrm{X}$ and $\mathrm{Y}$ being assumed to be of unit vari ance, their projections are inside a circle of radius 1 centered at the ori gin called correlation circle. Strongly associated (or correlated) variable $s$ are projected in the same direction from the origin. The greater the dist ance from the origin the stronger the association. Two circumferences of ra dius 1 and 0.5 are plotted to reveal the correlation structure of the varia bles (http://mixomics.org/graphics/variable-plots/plotvar/). 


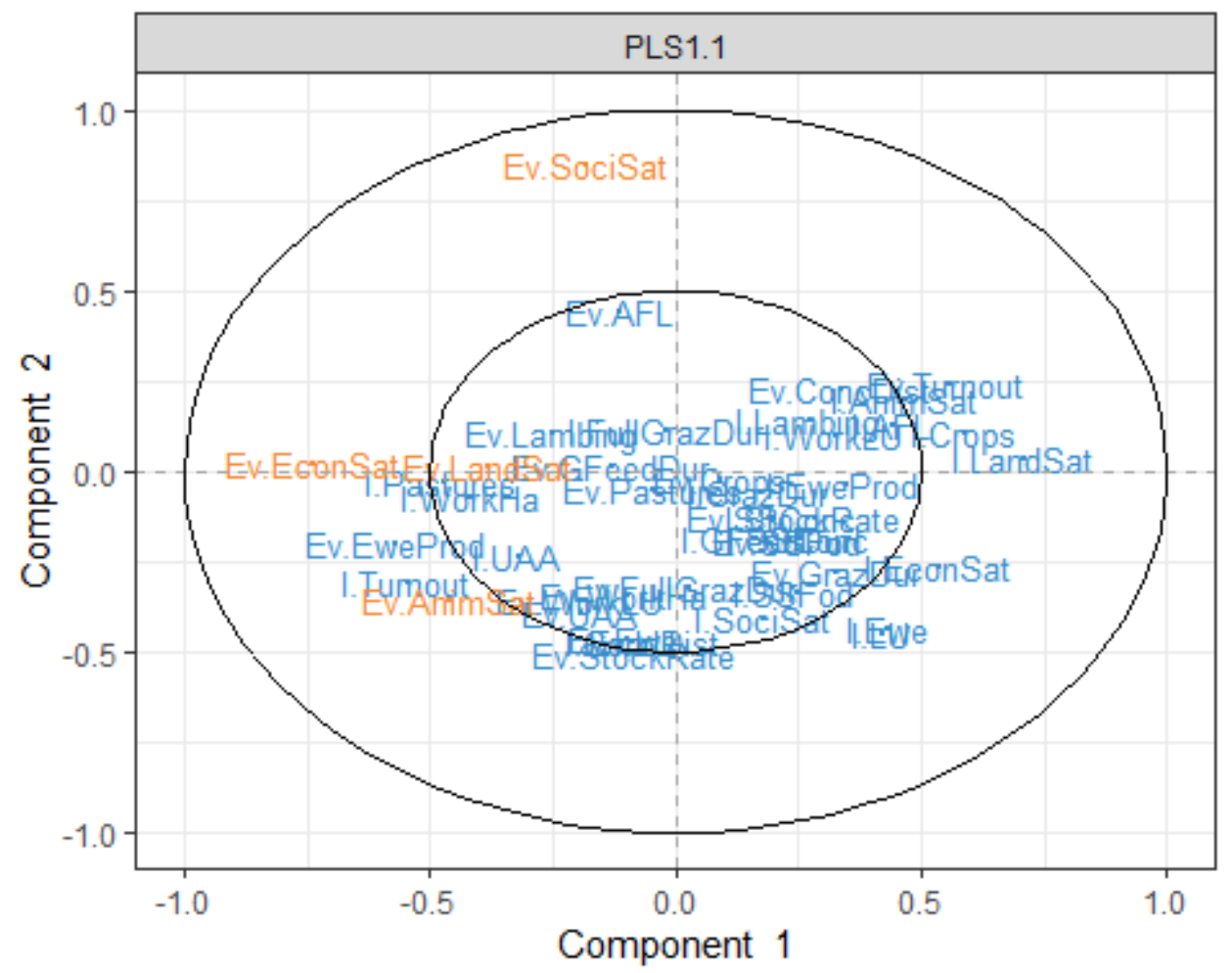

$\operatorname{par}(\operatorname{mfrow}=c(1,1))$

We aim at getting an as satisfying as possible model by performing SPLS after PLS. The quality of the pls and SPLS is assessed through graphs showing Q2 total, Q2 for each predicted variable and each component, R2 for each predicted variable and each component, and MSEP for each predicted variable and each component.

\# Model quality through Q2, R2 and MSEP:

tune.pls $=\operatorname{perf}(p l s$, validation="Mfold", folds=10, criterion="all", progres $\mathrm{sBar}=\mathrm{F}$, nrepeat $=50000$ )

plot(tune.pls\$Q2.total, $x l a b=" N u m b e r$ of PLS-components", ylab="Q2 total", ma in="PLS1.1 quality", $y \lim =c(-0.6,0.2))$

abline $(h=0.0975)$ 


\section{PLS1.1 quality}

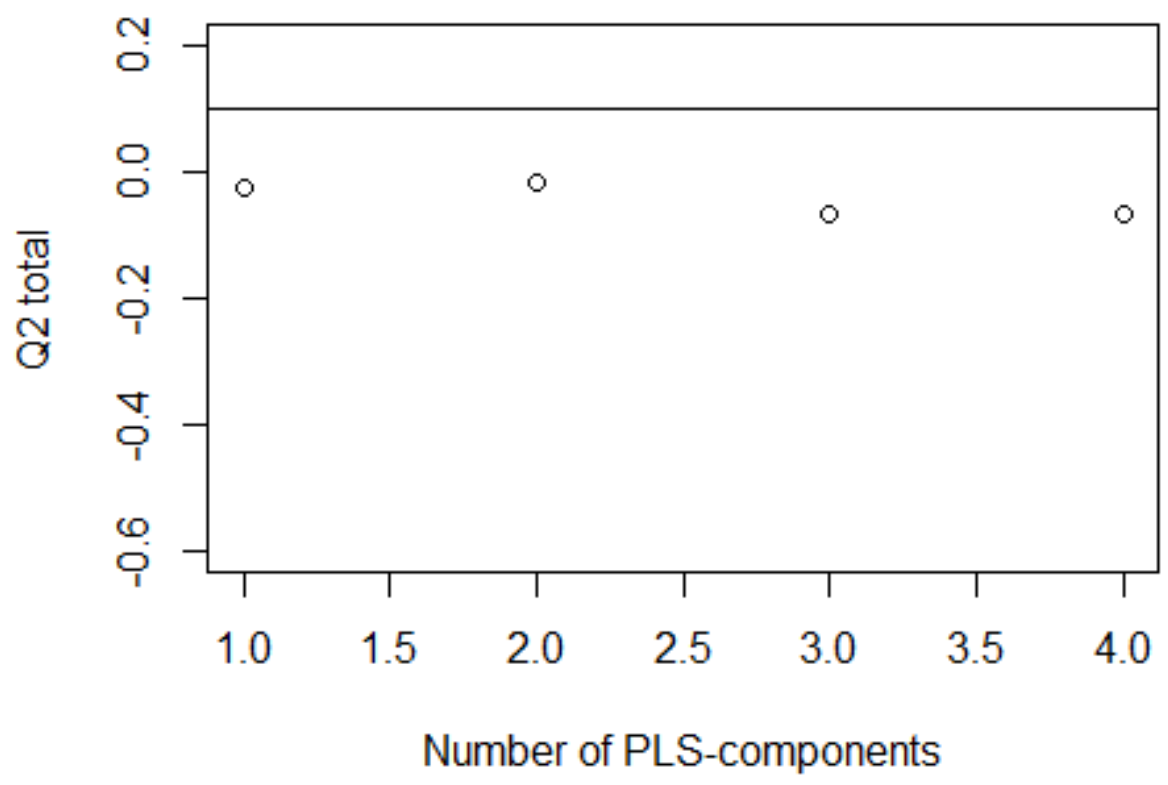

Overall quality of the model is below the ad hoc threshold of 0.0975 .

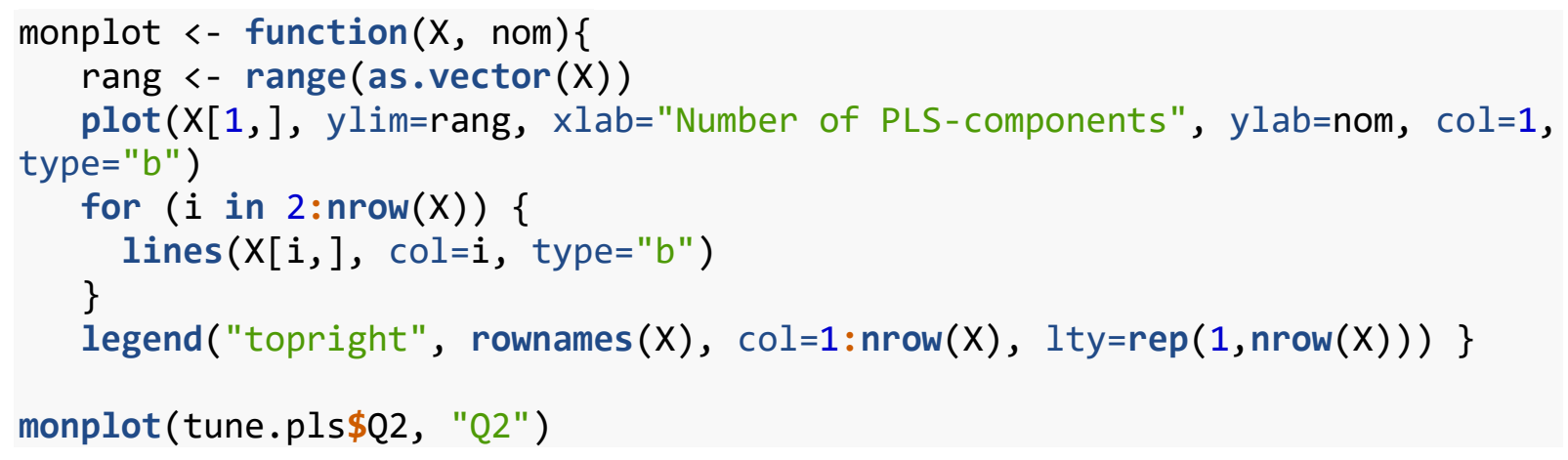




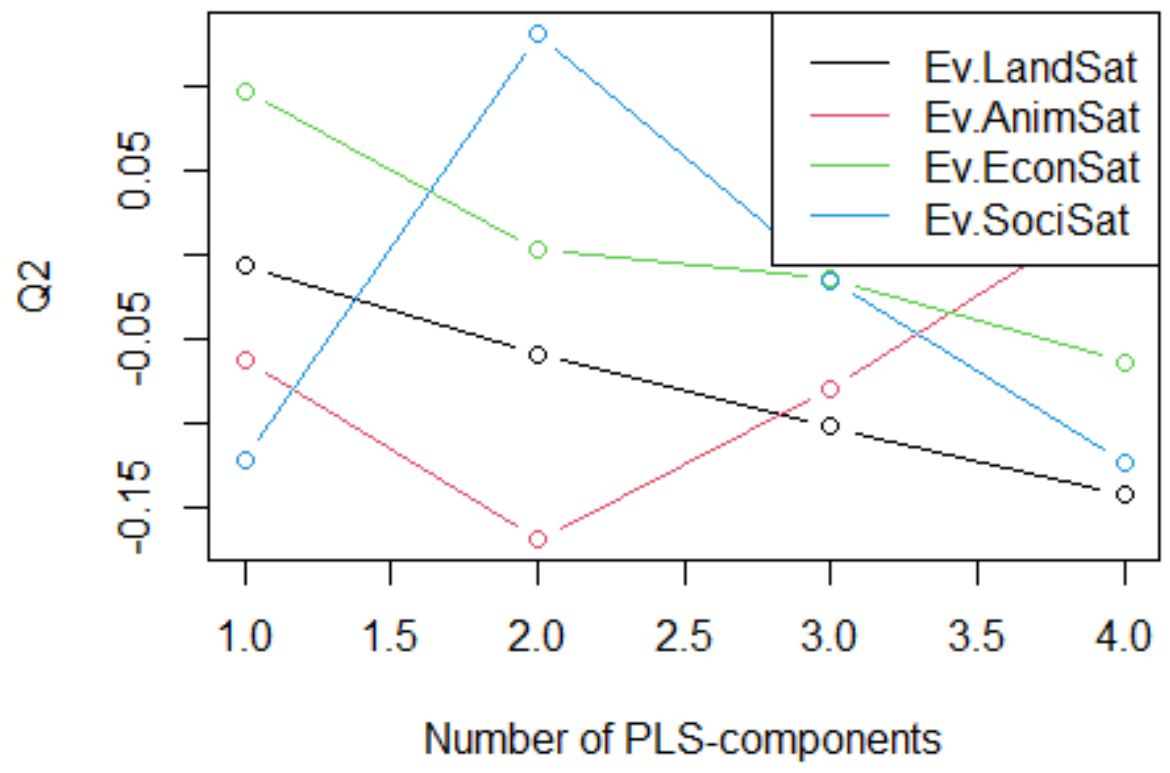

Low prediction quality for each dimension of satisfaction monplot(tune.pls\$R2, "R2")

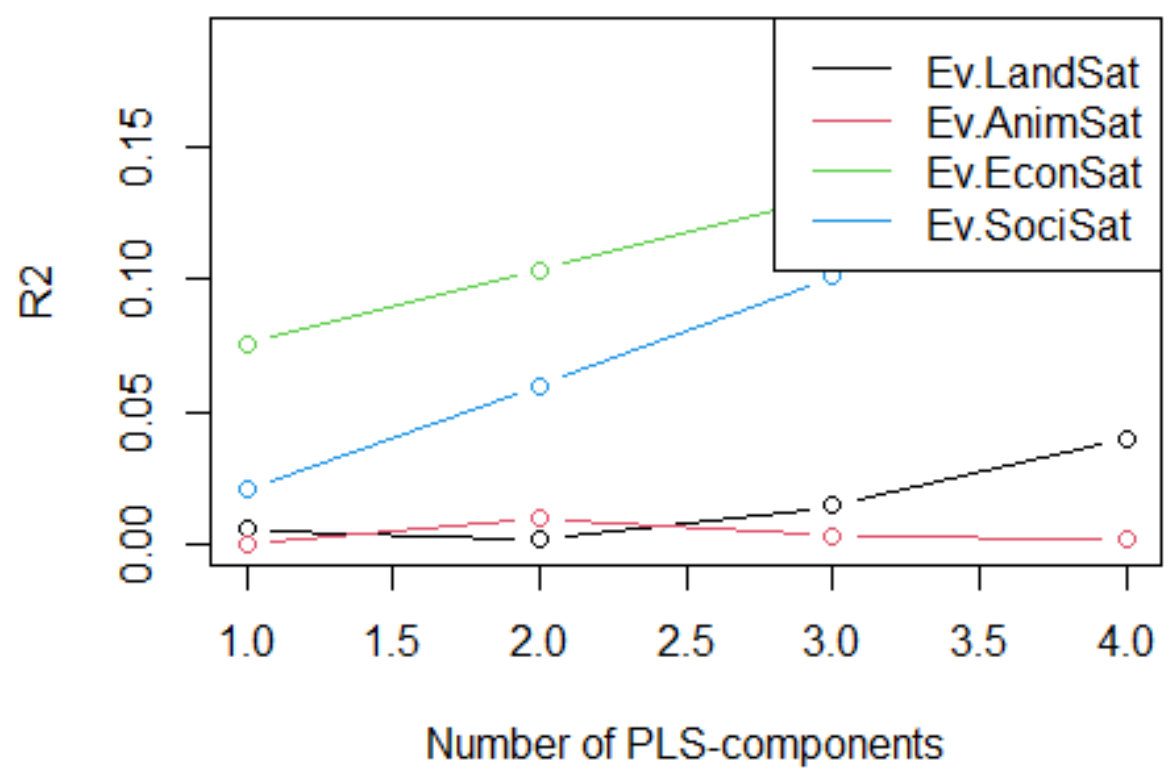

Low explanatory quality for each dimension of satisfaction monplot(tune.pls\$MSEP, "MSEP") 


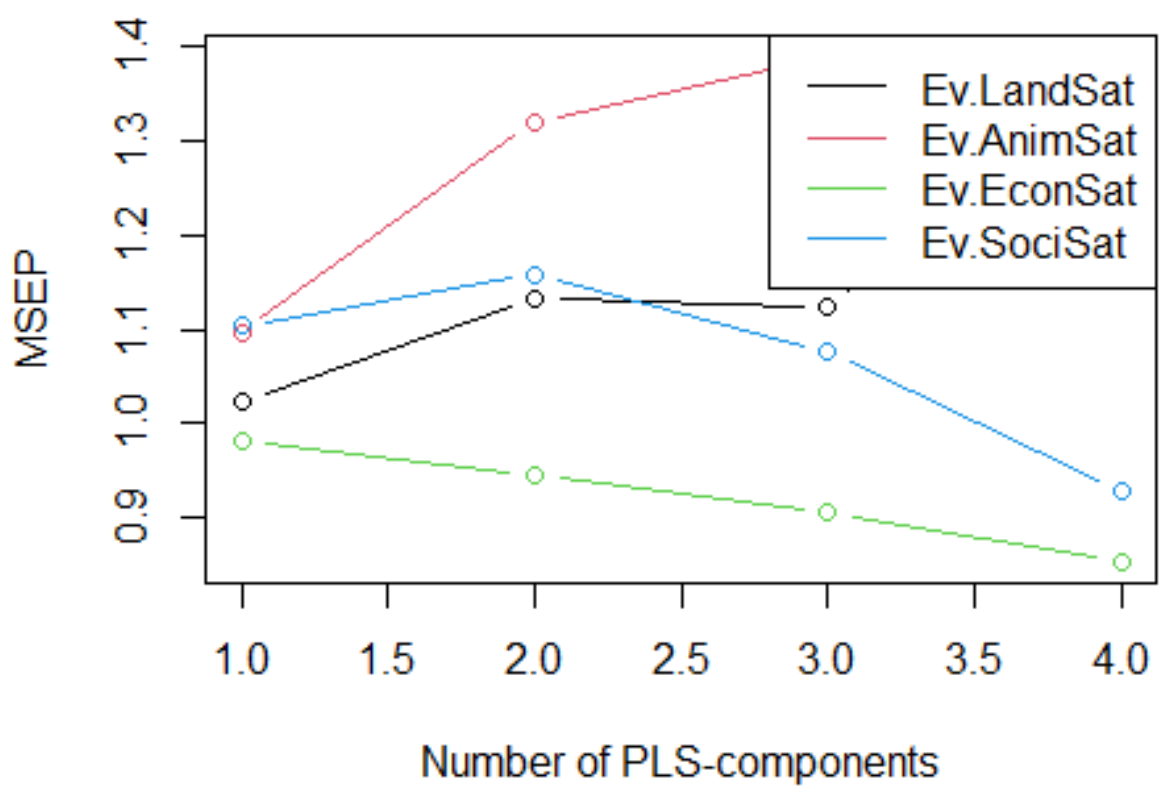

High Mean Squared Error of Prediction.

The quality of this PLS is too low.

We use the sPLS to improve model quality.

R code. Example for sPLS 1.1

\#Selection of variables to be kept in the sPLS, from PLS 1.1:

Tokeep<-tune.spls $(X, Y$, ncomp $=2)$

select. keepX $=$ Tokeep\$choice. keepX

\#SPLS 1.1

Spls $=\operatorname{spls}(X, Y, n c o m p=3$, mode $="$ regression", keepX $=$ select. keepX $)$

We draw the same graphs as for the PLS (i.e. PlotVar, Q2.total, Q2, R2, MSEP) 


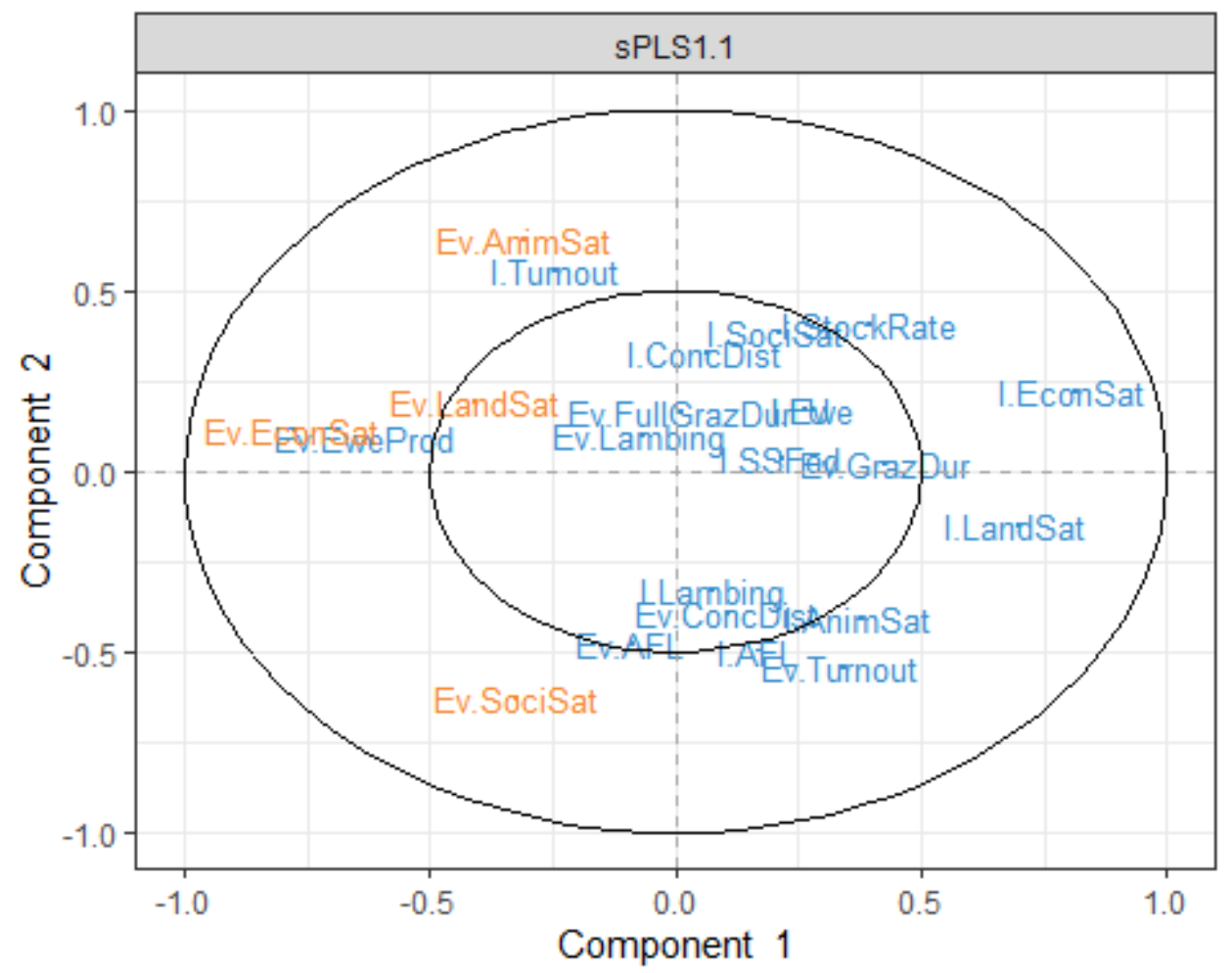

sPLS1.1 quality

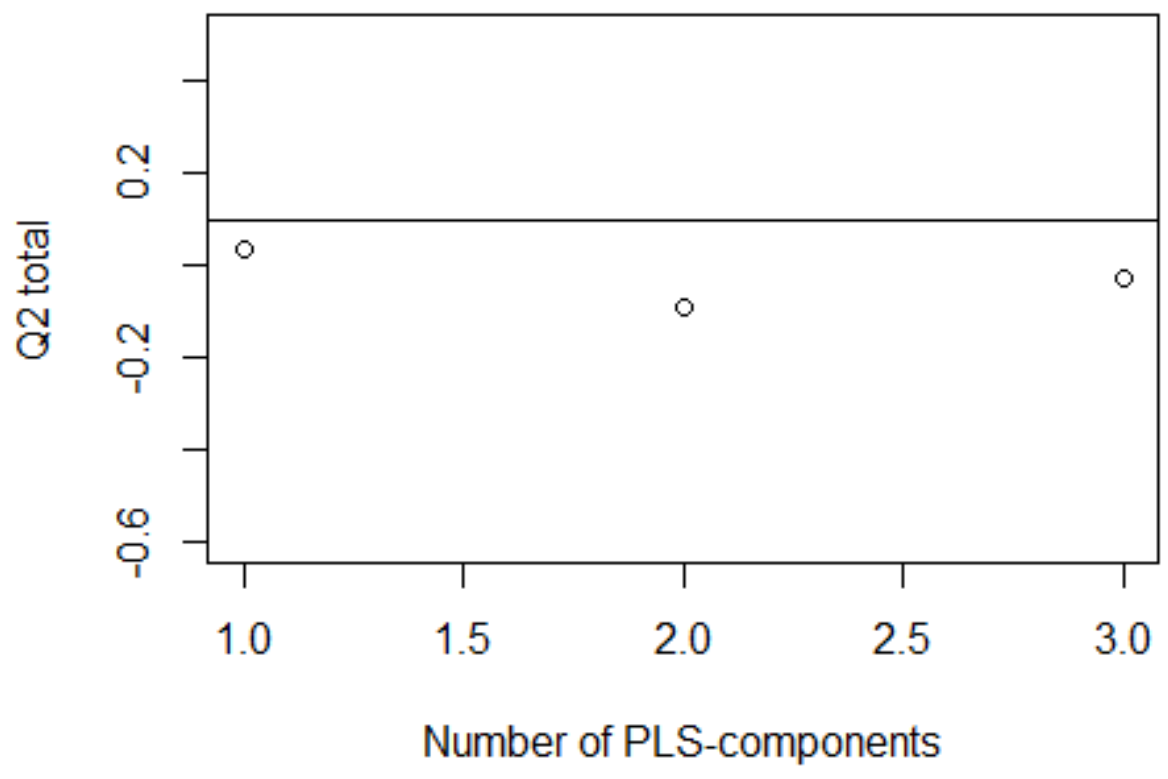



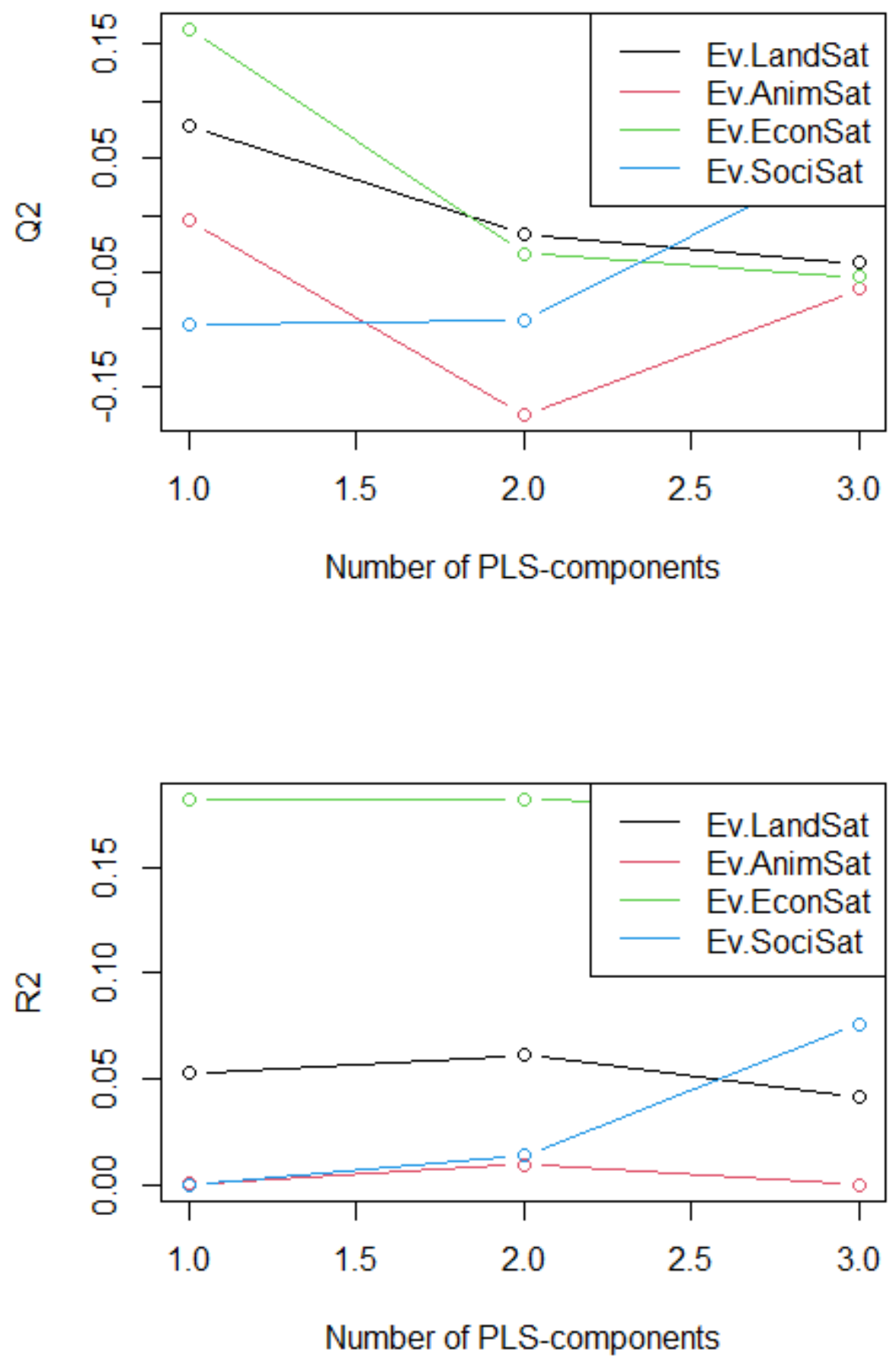


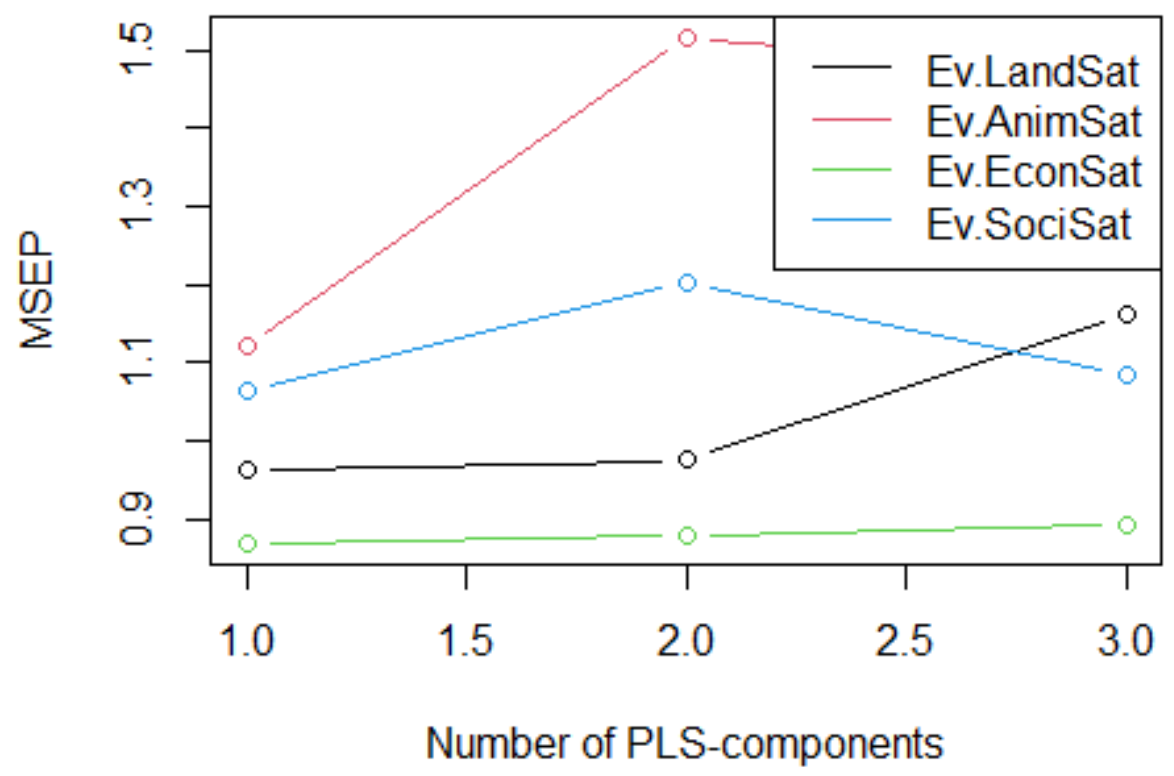

For the sPLS, Q2 is near the threshold on component 1 but often below and variable (the value slightly varies with each execution of the tune.pls() line of the code).

With the variables selected, the quality of the PLS and of the SPLS is too low to conclude. 
Using the same code as the one provided above, we performed a series of PLS and SPLS.

The following table summarizes the results.

\begin{tabular}{llclcccc} 
Model_Name & All_Var & Var_Selected & I_and_Ev & Ev_Only & Four_dim_Sat & Overall_Sat & Quality \\
\hline PLS1.1 & Yes & & Yes & Yes & too low \\
\hline sPLS1.1 & & Yes & Yes & Yes & low \\
\hline PLS1.2 & Yes & & Yes & Yes & Yes & Q2 acceptable but variable comp1 \\
\hline sPLS1.2 & & Yes & & & Yes & Q2 high and stable (comp1), unstable (comp2) \\
\hline
\end{tabular}

\begin{tabular}{lcccccc} 
PLS1.3 & Yes & & Yes & Yes & too low \\
\hline SPLS1.3 & & Yes & Yes & Yes & too low \\
\hline PLS1.4 & Yes & & Yes & & Yes & too low
\end{tabular}

$\begin{array}{lllll}\text { sPLS1.4 } & \text { Yes } & \text { Yes } & \text { Yes } & \text { Q2 acceptable but variable }\end{array}$

All_Var: PLS performed with all variables from the $X$ matrix

Var_Selected: Variables from the $X$ matrix are selected via sPLS

I_and_Ev: X matrix contains intercept values (I.) and slope values (Ev. for "Evolution")

Ev_Only: $X$ matrix contains slopes only

Four_dim_Sat: Y contains the values of evolution for the four dimensions of satisfaction (Ev.LandSat; Ev.AnimSat; Ev.EconSat; Ev.Soci.Sat)

Overall_Sat: Y contains the variable "Ev.OverallSat", an aggregation of the four dimensions of satisfaction

Quality: quality of the model for the different components (comp) according to obtained quality graphs 
sPLS 1.2 presented a high and stable value for Q2 on component 1. On this component, farmers' overall satisfaction increases when:

1-Estimated Overall satisfaction is lower at the conversion period

2-Ewe productivity increases

3-The duration of the grazing period decreases

Q2 was sometimes over the threshold on component 2 but was unstable

\section{Networks for association scores}

We draw networks to know association scores between response and explanatory variables.

$\mathrm{R}$ code for networks:

network(Spls,

comp $=1$,

color.node $=c($ "dodgerblue2", "orange1"),

show. edge. labels=TRUE,

cutoff $=0.3$,

lwd. edge $=6$,

interactive $=$ TRUE,

color.edge $=\operatorname{rep}(c($ "gray", "violet" $)))$

Corresponding graph:

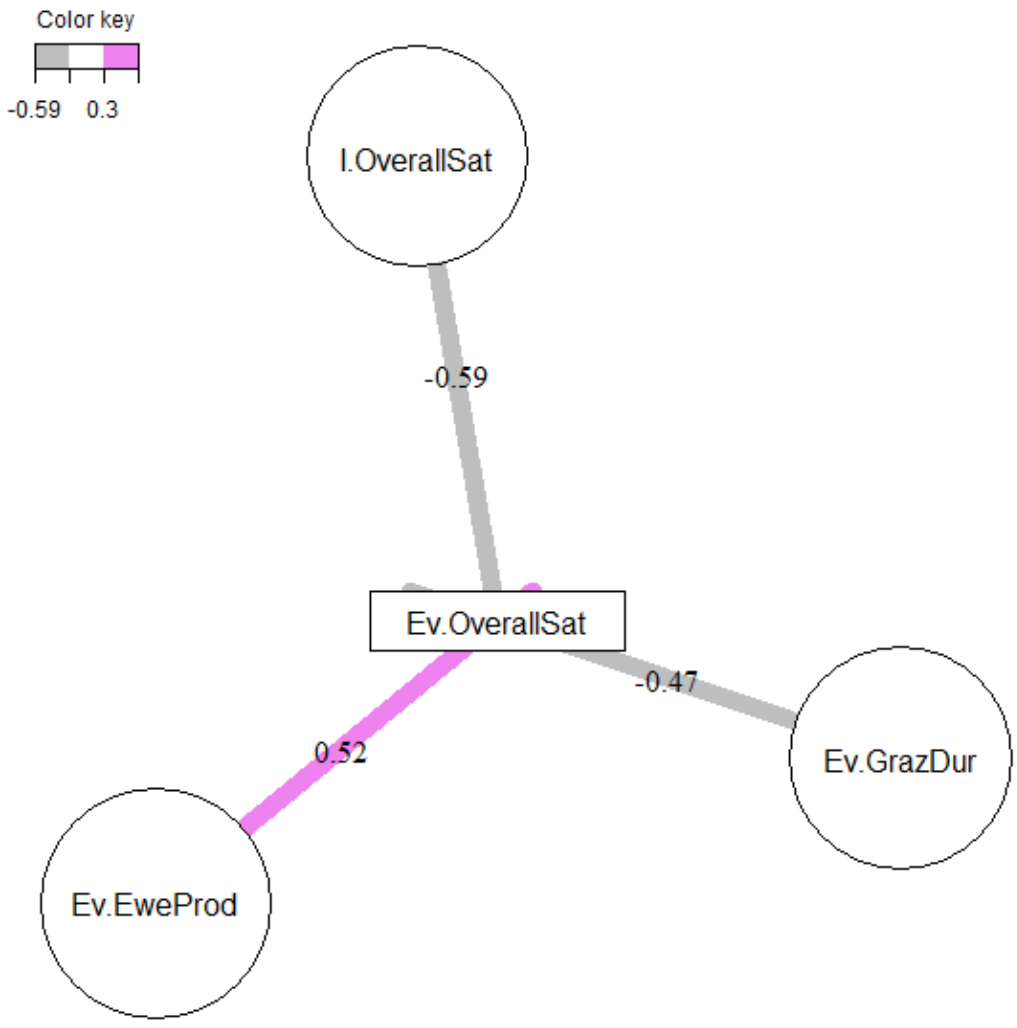


If we decrease the association score (cutoff=0.178), we obtain the following graph:

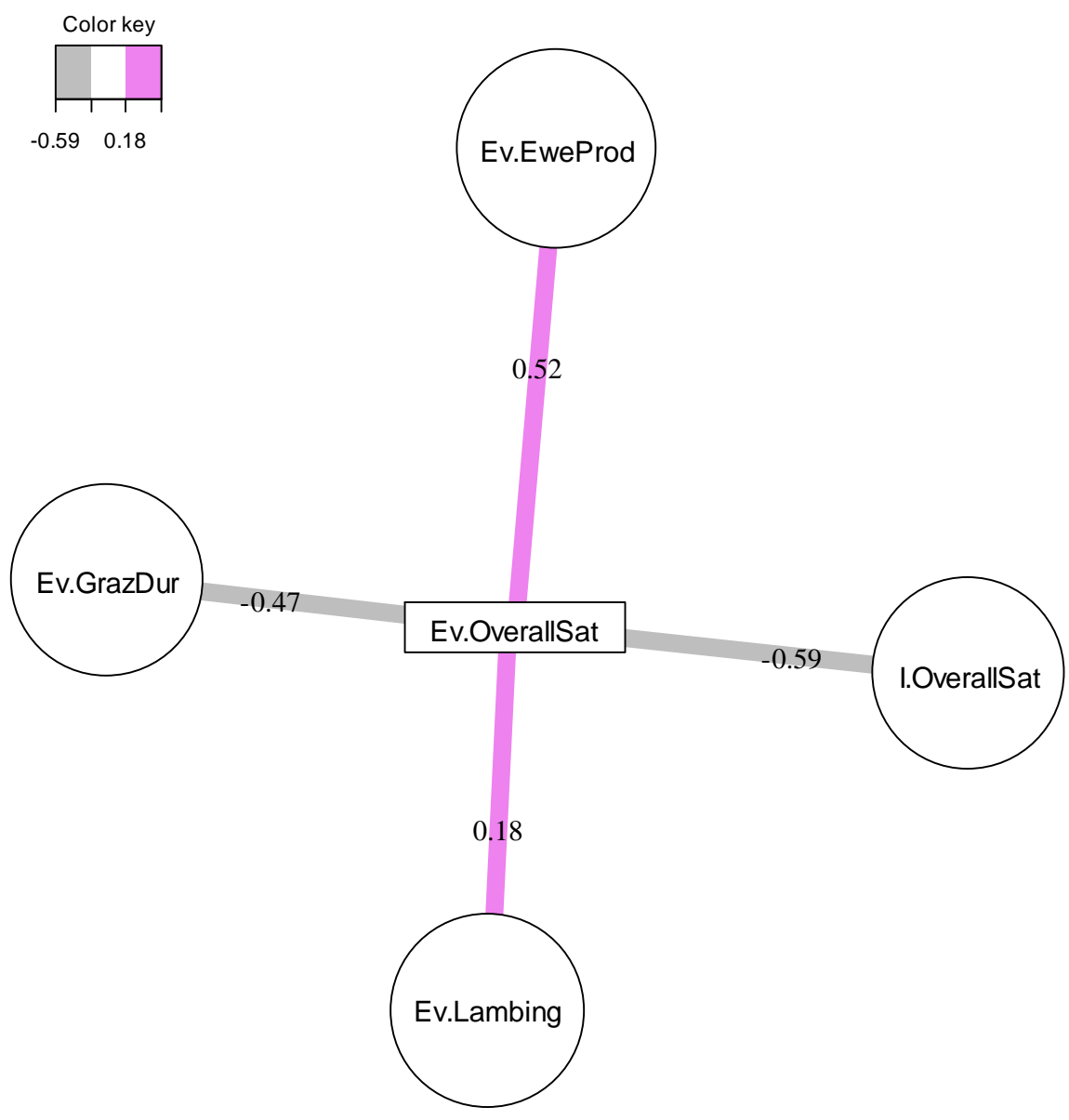

"Ev.Lambing" appears as a fourth explanatory variable. 